\title{
NEW FRONTIERS, OLD PROBLEMS: THE WAR ON TERROR AND THE NOTION OF ANTICIPATING THE ENEMY
}

\author{
Jackson Nyamuya Maogoto*
}

\begin{abstract}
[The old truism, that international law is not a suicide pact, is forceful in an age of destructive weaponry. Nevertheless strategically, there is little precedent for a major military offensive against a state that has not proximately used force against the interests of the belligerent state. Legally, while a number of legitimate justifications might permit the use of force, an appropriate international law doctrine, under which the United States could execute the military campaign it recently successfully launched against Iraq, does not currently exist. But that lacuna was seemingly plugged with the "Bush Doctrine" that advocates pre-emptive strikes against rogue states and /or entities involved in terrorism. The so-called "Bush Doctrine" articulates a new rule of international law that seeks to bring to life the doctrine of anticipatory self-defence as an appropriate means through which to combat terrorism (including states that actively support terrorism or that are themselves terror states in the sense of acquiring and stockpiling weapons of mass destruction).]
\end{abstract}

${ }^{*}$ LL.B (Hons)(Moi), LL.M (Hons) (Cantab), PhD (Melb), Lecturer in law, University of Newcastle. 


\section{NEW FRONTIERS, OLD PROBLEMS: THE WAR ON TERROR AND THE NOTION OF ANTICIPATING THE ENEMY}

["We must take the battle to the enemy, disrupt his plans, and confront the worst threats before they emerge." George W Bush Jr., US President $]^{1}$

[ "[With] [t]he Bush doctrine...The US president is hijacking the anti-terrorist agenda and crashing it into the most sacred skyscraper in New York: the headquarters of the UN. If his doctrine is not rapidly rejected by other states, preferably those which call themselves Washington's allies, Article 51 of the UN Charter will have suffered a mortal blow.” Jonathan Steele, Journalist $]^{2}$

["War on terrorism cannot be the guiding principle of US foreign policy-the most powerful country on earth preoccupied solely with self-preservation." George Soros, International Financier] $]^{3}$

\section{Introduction}

The law of permissible uses of force in international law dates back to ancient Greek and Hindu law. ${ }^{4}$ Following the Christianisation of the Roman Empire, the use of force abroad was driven by the just war doctrine. Under this doctrine, force could be used as long as it complied with the divine will. ${ }^{5}$ The foundation of this theory was that order was a deterrent to force, and force threatened order. ${ }^{6}$ At the time, war was used to punish wrongs and restore the status quo. During this time, St. Augustine elaborated and gave authority to the concept of just war and theorized that war for the purposes of aggression was unjust. ${ }^{7}$

The just war concept remained the dominant guide on lawful resort to war throughout the early centuries but developments in the fourteenth to sixteenth centuries rendered the already vague and easily manipulated concept almost meaningless in the face of the emergence of

\footnotetext{
${ }^{1}$ Commencement address by President George Bush at the West Point Military Academy graduation, June 1, 2002 , announcing an expansive new policy of pre-emptive military action. The speech can be accessed at the following URL < http://www.whitehouse.gov/news/releases/2002/06/20020601-3.html> (last visited May 1, 2003). ${ }^{2}$ See e.g. Jonathan Steele, The Bush Doctrine Makes Nonsense of the UN Charter, THE GUARDIAN, London (UK), Comment, June 7, 2002. This article can be accessed at the following URL http://www.guardian.co.uk/bush/story/0,7369,728870,00.html (last visited May 1, 2003).

${ }^{3}$ George Soros, Bush's Inflated Sense of Supremacy; FINANCIAL TIMES, London, (UK), Mar. 13 2003, at 13.

${ }^{4}$ See Sebastian Junger, The Forensics of War, VANITY FAIR, London, (UK) Oct. 1999, at 144.

${ }^{5}$ See MALCOLM N. SHAW, INTERNATIONAL LAW 777-78 (4th ed. 1997).

${ }^{6} \mathrm{Id}$. at 778 .

${ }^{7}$ IAN BROWNLIE, INTERNATIONAL LAW AND THE USE OF FORCE BY STATES, 5-6 (1963); SHAW, id. at 778; Leah Campbell, Defending Against Terrorism: A Legal Analysis of the Decision To Strike Sudan And Afghanistan, 74 TUL. L. REV. 1067, 1075-1076 (2000).
} 
independent princes and national states. ${ }^{8}$ In the seventeenth century however, a new standard on the use of force was articulated by Dutch lawyer Hugo Grotius generally acclaimed as the Father of International $\mathrm{Law}^{9}$ who redefined the just war theory as self-defence. ${ }^{10}$ Under the new theory of self-defence, force was permissible to protect property and punish wrongs suffered by citizens. ${ }^{11}$ In essence, Grotius refined the just war doctrine to exclude general evil contemplated by opposing states and required that some injury must have been suffered by the state that resorted to force. Soon after, the treaty of Westphalia in $1648^{12}$ dispensed with the just war doctrine entirely. ${ }^{13}$ The just war doctrine was replaced by a universal concept of state sovereignty that eviscerated the source of just war actions. Coming at the end of the period of violent religious wars in Europe, the treaty sought to establish a balance of power among states that was to last until $1914 .^{14}$

At the beginning of the $20^{\text {th }}$ century and particularly during the era of the League of Nations the freedom to resort to war became more and more restricted. The right of self-defence gained in significance displacing the expansive right of self-preservation. ${ }^{15}$ This development first

\footnotetext{
${ }^{8}$ With the emergence of independent princes and national states, scholars argued that a prince recognizing no de facto superior had the right to declare war. In essence, to be just a war was now not only confined to the vague motive of a just cause but also extended to a war waged by one who had the power to declare it. See BROWNLIE, supra note 7 , at $7-13$.

${ }^{9}$ There were many publicists before Grotius who wrote on special parts of the International law. Consequent to the centrality of war in international relations, these early authoritative treatises on international law focused on the laws of war and peace in a bid to regulate war and outlaw the international anarchy that was inherent in the sovereign right of war. These publicists are referred to by Oppenheim as 'Forerunners of Grotius.' Although Grotius owes much to Gentilis, he is nevertheless the greater of the two and bears by right the title of-Father of the International law. LASSA OPPEINHEIM, INTERNATIONAL LAW: A TREATISE (PEACE) $171\left(1^{\text {st }}\right.$ ed., 1905) Vol I.

${ }^{10}$ See HUGO GROTIUS, DE JURE BELLI AC PACIS LIBRI TRES Bk. I, ch. I, § II (1646), reprinted in 2 THE CLASSICS OF INTERNATIONAL LAW 172 (James Brown Scott ed. \& Francis W. Kelsey trans., 1925).

${ }^{11} I d$.

12 The treaty of Westphalia concluded the Thirty Years War and marked the first attempt by nation-states in Europe to establish a collective agreement as to use of force. See e.g. ANTONIO CASSESSE, INTERNATIONAL LAW IN A DIVIDED WORLD 34-35 (1986).

${ }^{13}$ Campbell, supra note 7, at 1076.

${ }^{14}$ BROWNLIE, supra note 7.

${ }^{15}$ In this Article the term self-defence is used in its contemporary meaning i.e., a lawful use of force in reaction to an armed attack or other territorial injury suffered by a state while anticipatory self-defence (and pre-emptive strikes) is used in the context of use of force by a state against another based on a perceived or potential threat of attack or injury to its territorial integrity.
} 
culminated in the conclusion of the Kellogg-Briand Pact in $1928 .{ }^{16}$ The general prohibition of war laid down in Article I of the Pact was subject only to the reservation of the right of selfdefence. ${ }^{17}$ Consequently, it was solely in the exercise of the right of self-defence that war could still be lawful. The failure of the League to enforce the constrains on the waging of warfare however paved the way for sovereign excesses leading to the outbreak of the Second World War. The end of the war saw the birth of the United Nations and another effort to put in place an international security regime to guarantee peace. With the adoption of the UN Charter, the course of events and legal developments subsequent to the Second World War reinforced the importance of the right of self-defence. Individual or collective self-defence became the cornerstone relating to use of force and since then has been invoked with regard to almost every use of external military force.

The volatile Cold War era that ushered in the UN era saw to it that any use of external military force by states was almost always pegged on the right of self-defence, with condemnation of any attempts to base the same on anticipatory self-defence. The dangers of a recognition of preemptive or anticipatory self-defence were easily understood. About four decades after the birth of the UN, the Cold War finally ended and a new era of hot peace was seemingly in the making. One thing remained constant and fixed-the justification for external use of military force by states (excepting UN authorized missions) remained firmly pegged on self-defence. However, the atmosphere of great optimism, a hope for reduced international tension and a greater chance for world peace masked the fact that most of the world's problems were not simply by-products of global politics a view that seemed to prevail during the political bipolarisation of the Cold War era. In particular, terrorism was gradually undergoing a

${ }^{16}$ General Treaty for the Renunciation of War, signed at Paris 27 August 1928, 94 L.N.T.S., 47, Treaty Series, No. 29 (1929); United States Statutes at Large Vol. 46, Part 2, p 2343 (hereinafter Kellogg-Briand Pact).

${ }^{17}$ Article I of the Kellogg-Briand Pact, id, provided: The High Contracting Parties solemnly declare in the names of their respective peoples that they condemn recourse to war for the solution of international controversies, and renounce it, as an instrument of national policy in their relations with one another. 
transformation into a separate, generic policy issue. The development of terrorism as a transnational enterprise would soon make it more than ever a separate unit of policy concern not simply for States, but the international community. The Cold War era policy of focusing on terrorist groups rather than terrorist attacks was now insufficient. Unilateral actions which had previously been the most appropriate response were now an insufficient basis for overall policy and a strain on international cooperation. Isolating terrorist groups and states supporting terrorism seemed the urgent (though not new) primary goal of international cooperation aiming at pressuring countries to make measures unilaterally or multinationally to deprive terrorist groups of mobility, safe havens and sources of income.

Increasingly, it was recognized that successful terrorists were choosing technology to exploit the vulnerabilities of modern societies. With citizens tending to live, work and travel in close proximity providing concentrated targets, modern societies are particularly susceptible to massive attacks and weapons that are capable of killing many people at one time-weapons of mass destruction. ${ }^{18}$ This fact was not lost on perpetrators of terrorism as witnessed by its growing capabilities and lethalness throughout the Cold War era and into the post-Cold War era. ${ }^{19}$ Though terrorism has always been high on the international agenda, it was the September 11,2001 attacks that brought the issue of terrorism and the international regime on the use of force into a new, urgent and sustained debate. With the US at the forefront, the emergence of terrorism as a global threat was forcing states of the world to adopt a new view of sovereigntyif a governing body cannot stop terrorists victimizing others from its territory, or if it offers safe havens and finance-then the government of the victim will reach across borders to do the necessary stopping. The strategy quickly crystallized into the so-called "Bush Doctrine" of hot

\footnotetext{
${ }^{18}$ JESSICA STERN, THE ULTIMATE TERRORISTS 4 (1999).

${ }^{19}$ Between 1970 and 1995, on average each year brought 206 more incidents and 441 more fatalities. STERN, id. at 6 .
} 
pre-emption or anticipatory self-defence..$^{20}$

This Article explores the notion of anticipatory self-defence that is encapsulated in the "Bush Doctrine". The "Bush Doctrine" is sweeping. Even without an imminent threat, US troops in the area or hostilities under way, the US President claims the right to launch military strikes. ${ }^{21}$ "Operation Enduring Freedom" in Afghanistan did have vestiges of self-defence but it is the invasion of Iraq that manifests the first clear-cut application of the "Bush Doctrine" and this has understandably divided the international community because it appears to privilege the "national interests" of the United States over the sovereignty of other states-a strong echo of the right of self-preservation and its collorary, anticipatory self-defence. During its heydays, anticipatory self-defence was intertwined with the right of self-preservation but as already mentioned, this right fell into disrepute in the early part of the $20^{\text {th }}$ century with the imposition of international legal restraints on the right to wage war hiving off the sub-category of anticipatory self-defence in favour of the more determinate right of self-defence.

Part II offers an insight into the tenets of the "Bush Doctrine" mentioning the Afghanistan invasion and then delving into the Iraqi invasion. Part III of the Article centres the problem with the "Bush Doctrine" a development that takes the world back to its nineteenth century condition, permitting states to attack each other based on anxiety about their neighbours' military strength and intentions. The Part explores the doctrine of anticipatory self-defence in the early days of the modern international system and its movement into the $20^{\text {th }}$ century, the era of the legal prohibition of force. Under discussion is the landmark Caroline incident which laid down the important criteria for the use of force in anticipatory self-defence but also

\footnotetext{
${ }^{20}$ See e.g. Steele, supra note 2; William Safire, Comment, THE AGE, Melbourne (AUSTRALIA) June 8, 2002, at 21.

21 "Our security will require transforming the military you will lead," ... "The military must be ready to strike at a moment's notice in any dark corner of the world. All nations that decide for aggression and terror will pay a price." Westpoint Commencement Speech, supra note 1.
} 
significantly contributed important benchmarks to self-defence generally. Further, the notion of reprisals (retaliatory acts) which often has accompanied the notion of pre-emption in relation to reaction to terrorist attacks is covered. Part IV, moves on to discuss the doctrine of self-defence as enshrined in the UN Charter. Part V of the Article addresses the question whether anticipatory-self-defence is permitted under the UN Charter and seeks to bring out the prevailing arguments raised by opponents and proponents. The issues that the Article tackles are obviously complex and lengthy, however the Article has as its modest goal the exploration of the general arguments that anticipatory self-defence raises.

\title{
II. Rushing to Break The Law? The "Bush Doctrine"
}

On October 1, 1985, six F-15 Israel fighter-bombers unleashed a barrage of bombs on the headquarters of the Palestine Liberation Organization in a suburb of Tunis, the capital of Tunisia, responding to alleged terrorist attacks. ${ }^{22}$ The United Nations Security Council with only one abstention by the United States was swift to vigorously condemn the act of armed aggression perpetrated by Israel against Tunisian territory in flagrant violation of the Charter of the United Nations, international law and norms of conduct. ${ }^{23}$ Ambassador Vernon Walters, while explaining the United States abstention, touched on the defensive use of force in the following terms:

\begin{abstract}
We, however, recognize and strongly support the principle that a state subjected to continuing terrorist attacks may respond with appropriate use of force to defend against further attacks. This is an aspect of the inherent right of self-defence recognized in the United Nations Charter. We support this principle regardless of attacker and regardless of victim. It is the collective responsibility of sovereign states to see that terrorism enjoys no sanctuary, no safe haven, and that those who practice it have no immunity from the responses their acts warrant. Moreover, it is the responsibility of each state to take appropriate steps to prevent persons or groups within its sovereign territory from perpetrating such acts. ${ }^{24}$
\end{abstract}

\footnotetext{
${ }^{22}$ The Israeli attack by six F-15 fighter-bombers apparently left 70 men, women and children dead and more than 100 Tunisians and Palestinians wounded. See Cycle of Terrorism Will Continue With Retaliatory Strikes, Hous. Post, Jan. 2, 1986, at 2B, col. 1.

${ }^{23}$ UN Doc. S/RES/573 (Oct. 4, 1985) (vote: 14-0-1), reprinted in 24 I.L.M. 1740-41 (Nov. 1986), extract reprinted in 80 AM. J. INT'L. L. 166 (1986).

${ }^{24}$ U.S. Mission to the UN Press Release No. 106 (85), Oct. 4, 1985, extract reprinted in 80 AM. J. INT'L L. 166,167 (1986).
} 
About three months later, on January 15, 1986, US Secretary of State, George Shultz formally announced the "Shultz Doctrine". He asserted: "It is absurd to argue that international law prohibits us from capturing terrorists in international waters or airspace, from attacking them on the soil of other nations even for the purpose of rescuing hostages, or from using force against states that support, train and harbour terrorists or guerrillas." ${ }^{25} \mathrm{He}$ further added: "A nation attacked by terrorists is permitted to use force to prevent or pre-empt future attacks, to seize terrorists, or to rescue its citizens, when no other means is available." 26

Worldwide opposition to the doctrine was swift in coming. Surprisingly some senior officials in the US State Department expressed reservations. ${ }^{27}$ More importantly, US Secretary of Defence Casper Weinberger, in charge of the machinery that would be tasked with effecting the doctrine opposed responsive military strikes that needlessly "kill women and children"،28 Additionally, Robert Oakley, ambassador-at-large for counter terrorism, opined that the President's Commission on Terrorism had recommended that the United States not use military force to retaliate against states supporting terrorists. ${ }^{29}$ International and domestic opposition in the US was owing to a number of difficult issues raised by the doctrine which Professor Jordan J. Paust identified succinctly as: “... [I] s the responding coercion still a use of force in selfdefence against an armed 'attack'? Is the responding coercion primarily pre-emptive,

\footnotetext{
${ }^{25}$ See, Shultz Urges Limited Attack On Terrorists, HOUSTON CHRONICLE, Houston, (USA) Jan. 16, 1986, at 6, col. 3; Shultz Supports Armed Reprisals, NEW YORK TIMES, New York (USA) Jan. 16, 1986, at A1, col. 5. The entire speech is now reprinted in 25 I.L.M. 204 (Jan. 1986). For quoted language, see id. at 206.

${ }^{26} I d$.

${ }^{27}$ See e.g., Abraham Sofaer--State's Legal Adviser Deals With Policy, Then the Law, WASHINGTON POST, Washington (USA) Mar. 10, 1986, at A13, col. 1.

${ }^{28}$ See, Task Force Supports U.S. Policy On Global Terrorism, Official Says, HOUSTON POST, Houston, (USA) Mar. 2, 1986, at A13, col. 3.

${ }^{29}$ Id at col. 3-4.
} 
retaliatory, or for the purpose of imposing sanctions against a violation of international law? And if among the latter, are any of these forms of responsive coercion ever permissible?" 30

The authoritative condemnation of the Israeli strikes was but an example of a much longer history of condemnations of both pre-emptive and retaliatory reprisal actions which are generally viewed as inconsistent with the Purposes of the United Nations. ${ }^{31}$ Professor Jordan J. Paust reacting to the unpalatability of the "Shultz Doctrine" noted that "the predominant expectation is that merely pre-emptive and retaliatory reprisal actions as such are impermissible. For this reason, implementation of the "Shultz Doctrine" by the use of preemptive or retaliatory reprisal forms of force would place the United States in violation of international law and must be opposed." 32

The "Shultz Doctrine" was part of the growing attempt in the 1980s to find new avenues within the international framework on the use of force to combat the increasing number and lethality

\footnotetext{
${ }^{30}$ Jordan J Paust, Responding Lawfully to International Terrorism: the Use of Force Abroad, 8 WHITTIER L REV. 711, 716 (1986).

${ }^{31}$ See, e.g., the 1970 Declaration on Principles of International Law, supra note 15 ("duty to refrain from any acts of reprisal involving the use of force"); S.C. Res. 188, 19 UN SCOR, Supp. April-June 1964, at 9, UN Doc. S/5650 (1964); D. BOWETT, SELF-DEFENSE IN INTERNATIONAL LAW 154-55 (1958) (reprisals); J. BRIERLY, THE LAW OF NATIONS 401, 412, 412, 426 (6 ed. 1963) (reprisals); I. BROWNLIE, INTERNATIONAL LAW AND THE USE OF FORCE BY STATES 275-79 (anticipatory self-defense), 281,431 (reprisals) (1963); L. HENKIN, HOW NATIONS BEHAVE 141-44 (2 ${ }^{\text {nd }}$ ed. 1979) (anticipatory self-defense); P. JESSUP, A MODERN LAW OF NATIONS 166-67 (3d ed. 1968) (anticipatory self-defense); H. KELSEN, THE LAW OF THE UNITED NATIONS 797-98 (1950) (anticipatory self-defense); J. KUNZ, THE CHANGING LAW OF NATIONS 571- 72 (1968) (anticipatory self-defense); R. Lillich, Humanitarian Intervention: a Reply to Ian Brownlie and a Plea for Constructive Alternatives, in LAW AND CIVIL WAR IN THE MODERN WORLD 229, 244 (J. Moore ed. 1974); Brownlie, The Use of Force in Self-Defence, 37 BRIT. YRBK. INT'L L. 266 (1962) (anticipatory self-defense); Bowett, Reprisals Involving Recourse to Armed Force, 66 AM. J. INT'L L. 1, 1-2, 7 , 21, 33-6 (1972) (reprisals); Rosenstock, The Declaration of Principles of International Law Concerning Friendly Relations: A Survey, 65 AM. J. INT'L L. 713, 719 (1971) (reprisals); Willis, supra note 18, at 489-92 (1979); Zedalis, supra note 20, at 117-25, 167 (reprisals); letter of Acting Sec. of State Rush of May 29, 1974 to Prof. Rostow, reprinted at 68 AM. J. INT'L L. 736 (1974) (reprisals); see also Military and Paramilitary Activities in and against Nicaragua, (Nicar. v. U.S.), 1986 I.C.J. (1986) (no right to use force in self-defense unless there is an 'armed attack'); R. HIGGINS, THE DEVELOPMENT OF INTERNATIONAL LAW THROUGH THE POLITICAL ORGANS OF THE UNITED NATIONS 200-05, 217-18 (1963); J. BRIERLY, THE LAW OF NATIONS 418-21 (6th ed. 1963) (anticipatory self-defense); A. THOMAS \& A. THOMAS, NONINTERVENTION 123-24 (1956).

${ }^{32}$ Paust, supra note 30, at 719 .
} 
of international terrorist acts. ${ }^{33}$ Domestic and international mechanisms had proven to be spectacularly ineffective in dealing with the terrorist threat. Despite hundreds of terrorist attacks international terrorists continued to elude justice. Attempts to have terrorists captured and extradited often fail and the trend then and now is much the same. In view of poor international cooperation, states (notably the US and Israel) increasingly demonstrated an inclination to resort to forcible self-help. ${ }^{34}$ These actions met with varying degrees of condemnation. ${ }^{35}$ September 11,2001 seemed to change all that. In a coordinated operation whose breadth and audacity stunned the world, terrorists believed to be part of the Al Qaeda network carried out the worst terrorist attack in modern times targeting the symbols of US supremacy leaving about 3000 people dead. ${ }^{36}$ The day after the attacks, the UN Security Council tersely stated that: "The magnitude of [the] acts goes beyond terrorism as we have known it so far ... We therefore think that new definitions, terms and strategies have to be developed for the new realities." 37

Amidst a swell of international support (which would soon begin to ebb), the United States

\footnotetext{
${ }^{33}$ On December 27, 1985, bombs struck airline offices in Rome and Vienna, killing twenty civilians, including five Americans, and injuring eighty others. No conclusive evidence linked Libya to the attacks, but the passports employed by the Arab attackers were traced to Libya. On April 4, 1986 (April 5 in Germany), a bomb exploded in La Belle Discotheque, a nightclub in West Berlin frequented by American GIs, killing three and wounding over 150 others, including fifty to sixty Americans. Then US President Ronald Reagan responded promptly to this paradigmatic state-authorized terrorist attack. On April 14, 1986, U.S. fighter planes bombed military and paramilitary targets in Libya, including airfields, intelligence facilities, and terrorist training camps. In the two weeks that followed the raid, acts of violence occurred which were apparently retaliation for the bombing of Libya. At least five killings were attributed to groups with Libyan sympathies. Several bombings and attempted bombings were thought to be retaliatory measures taken in response to the American bombing. Explosions ripped through American business offices in France and British business offices in Lebanon. Throughout the world, threats were made on American installations. For a discussion of this incidents and the responses, See e.g. Gregory Francis Intoccia, American Bombing Of Libya: An International Legal Analysis, 19 CASE W. RES. J. INT'L L. 177 (1987); W. Michael Reisman, International Legal Responses To Terrorism, 22 HOUS. J. INT'L L. 3 (1999).

${ }^{34}$ See discussion in Part V of this Article.

${ }^{35}$ See discussion in Part V of this Artcle.

${ }^{36}$ Four commercial aircraft were hijacked, two of them were flown into the twin towers of the World Trade Center in New York City, causing both buildings to collapse, a third aircraft crashed into the Pentagon building in Arlington, Virginia, which houses the headquarters of the U.S. Department of Defense and the U.S. armed forces, the fourth aircraft, crashed near Somerset, Pennsylvania. Rensselaer Lee \& Raphael Perl, Congressional Research Service, Order Code IB95112, Terrorism, the Future, and U.S. Foreign Policy 1 (Aug. 6, 2002).

${ }^{37}$ Statement of Ambassador Valeriy Kuchinsky, Ukrainian Representative to the United Nations. Transcript of the 4370th meeting of the Security Council, at 3, UN Doc. S/PV.4370 (Sep. 12, 2001).
} 
quickly identified the Al Qaeda terrorist network with the support of the Taliban government, as the perpetrators of the September 11, 2001 terrorist attacks. ${ }^{38}$ This was coupled with a recognition that the modern threat to US power and security rises not from one particular organization, but from the growing threat of international terrorism, particularly terrorism that enjoys active or tacit state support. " ${ }^{39}$ "Operation Enduring Freedom" in Afghanistan signalled a renewed determination on the part of the United States to combat international terrorism and states that sponsor it, but the operation laid fertile ground for debate on the strategic or legal approach that States should adopt in responding to such threats. Strategically, the US military action against terrorism was based on the Reagan-era doctrine of "swift and effective retribution" against terrorist organizations that strike US interests. ${ }^{40}$ Though legally, the United States justified "Operation Enduring Freedom" under the established doctrine of self-defence, ${ }^{41}$ talk from Washington was articulating pre-emptive self-defence. Essentially, the US did not consider military action against Afghanistan as a formal war against the state but pre-emption of further attacks by terrorists based in that State. As the US moved against Afghanistan, the highest levels of military, legal, and diplomatic policymakers in Washington began debating how the United States should confront states that sponsor terrorism and proliferate weapons of mass destruction. The immediate focus of that debate cantered on US policy towards Iraq.

\footnotetext{
${ }^{38}$ See President George W. Bush, Address to a Joint Session of Congress and the American People, in 37 WEEKLY COMP PRES. DOC. 1347 (Sept. 20, 2001) ("The evidence we have gathered all points to a collection of loosely affiliated terrorist organizations known as al [sic] Qaeda.").

${ }^{39}$ The war on terror "will not end until every terrorist group of global reach has been found, stopped and defeated. ... From this day forward, any nation that continues to harbor or support terrorism will be regarded by the United States as a hostile regime." President George W. Bush, Address to a Joint Session of Congress and the American People, $i d$.

${ }^{40}$ WESTERN RESPONSES TO TERRORISM: A TWENTY-FIVE YEAR BALANCE SHEET 307, 316 (Ronald Crelinsten \& Alex P. Schmid eds., 1992). The policy described by Crelinsten and Schmid has clearly been continued by Reagan's successors. This is evident in Clinton's air strikes against Iraq for the attempted assassination of George H.W. Bush and his strikes against Sudan and Afghanistan following the Embassy Bombings in Tanzania and Kenya.

${ }^{41}$ For a discussion of the international legal validity of U.S. military action "Operation Enduring Freedom" in Afghanistan, see Jack Beard, America's New War on Terror: the Case for Self-Defense under International Law, 25 HARV. J. L. \& POL'Y 559, 559 (2002).
} 
Soon after the military action in Afghanistan, the "Axis of Evil" speech provoked heated reaction with its strong overtones of unilateral military action by the US against countries that support terror and an intimation of expansion of the scope of military operations beyond Afghanistan without indication that such an expanded theatre of operations would depend on Security Council approval. ${ }^{42}$ Though the genesis of the "Bush Doctrine" can be traced to the immediate aftermath of the September 11 attacks, ${ }^{43}$ it was five months after the "Axis of Evil" speech that the US President delivered the fullest exposition of the doctrine in a speech at West Point on June $1 .{ }^{44}$ Warning that the United States faced "a threat with no precedent" through the proliferation of weapons of mass destruction and the emergence of global terrorism, Bush stated that the traditional strategies of deterrence and containment were no longer sufficient. Because of the new threats that the United States faces, he claimed that a proper understanding of the right of self-defence would now extend to authorizing pre-emptive attacks against potential aggressors, cutting them off before they are able to launch strikes against the US that might be devastating in their scale and scope. Under these circumstances, he concluded, "If we wait for threats to fully materialize, we will have waited too long." 45 Expounding on the strategic aspect of the doctrine, President Bush stated that there was a need to "... take the battle to the enemy, disrupt his plans, and confront the worst threats before they emerge." ${ }^{46}$ In the same address, he went on to tell the future US military officers at West Point that: "The military must be ready to strike at a moment's notice in any dark corner of the world. All nations that decide for aggression and terror will pay a price." 47 That doctrine carried an explicit warning for Iraq and other states that pursue weapons of mass destruction: if a hostile

\footnotetext{
${ }^{42}$ The President's State of the Union Address, Jan. 29, 2002. This can be accessed at the following URL <http://www.whitehouse.gov/news/releases/2002/01/20020129-11.html>.

${ }^{43}$ Nine days after the attacks, U.S. President George Bush announced that: "[f]rom this day forward, any nation that continues to harbor or support terrorism will be considered by the United States as a hostile regime." President George W. Bush, Address to a Joint Session of Congress and the American People, supra note 38.

${ }^{44}$ Westpoint Commencement Speech, supra note 1.

${ }^{45}$ Westpoint Commencement Speech, supra note 1.

${ }^{46}$ Id.

${ }^{47}$ Id.
} 
regime also pursues the acquisition or development of chemical, biological or nuclear weapons, the decisive use of anticipatory military force to end that regime is a legitimate response.

Iraq was particularly prominent on the list of places where military intervention was envisioned. ${ }^{48}$ In the case of Iraq, the United States and United Kingdom successfully encouraged the UN Security Council to pass Resolution $1441,{ }^{49}$ which gave Iraq a final opportunity to comply with its disarmament obligations through weapons inspections. Chafing impatiently at the slow pace of the UN weapon's inspection process, the US rashly assumed evidence of Iraqi involvement with terrorist activity and of persisting Iraqi capacity for weapons of mass destruction. ${ }^{50}$ The US position quickly crystallized as one of armed

\footnotetext{
${ }^{48}$ Thom Shanker \& David E. Sanger, U.S. Envisions Blueprint on Iraq Including Big Invasion Next Year, NEW YORK TIMES, New York, (USA) Apr. 28, 2002, at A1 (reporting that direct military involvement is being considered after the Bush Administration concluded that a coup in Iraq would be unlikely to succeed); Patrick E. Tyler, U.S. Again Placing Focus on Ousting Hussein, NEW YORK TIMES, New York, (USA) Dec. 18, 2001, at A1 (reporting that "[t]he option of taking the war against terrorism to Iraq and Saddam Hussein has gained significant ground in recent weeks"). Although the United States appears to be seeking Security Council approval for the use of force against Iraq, it has reserved the right to proceed independently in the event such approval fails to materialize and the United States deems force to be necessary in self-defense. The use of force against Iraq in the event of non-compliance with weapons inspections received support from some, but not all, U.S. allies. See also, John Ibbitson, Bush Rallies Support for Wider War, GLOBE \& MAIL, Toronto, (CANADA) Mar. 12, 2002, at A1 (discussing the United Kingdom's support); Julia Preston \& Eric Schmitt, U.S.-French Split on Iraq Deepens, NEW YORK TIMES, New York, (USA) Oct. 15, 2002, at A1 (discussing French opposition to U.S. action in Iraq); U.S. Offers a Deal for UN Resolution on Iraq, NEW YORK TIMES, New York, (USA) Oct. 17, 2002, at http://www.nytimes.com (on file with the North Carolina Law Review) (reporting that two dozen nations have refused to endorse military force if Iraq fails to comply with weapons inspections).

${ }^{49}$ S.C. Res. 1441, UN SCOR, 57th Sess., 4644th mtg., UN Doc. S/Res/1441 (2002). The UN Security Council unanimously passed Resolution 1441. The resolution declared Iraq to be in material breach of its obligations under past UN mandates. It also informs Iraq it will face "serious consequences" if it fails to cooperate. It is questionable whether it authorizes a member-state to unilaterally take action in the event of further noncompliance.

${ }^{50}$ Much debate initially surrounded the credibility of the US evidence regarding Iraq's links to Al Qaeda. The issue of the possession of weapons of mass destruction, the quantity and nature were matters of much controversy. Initially it was difficult to conclude one way or the other but the international community remained divided over the matter right up to the day of military action. See e.g., Chris Hedges, Defectors Cite Iraqi Training for Terrorism, NEW YORK TIMES, New York, (USA) Nov. 8, 2001, at A1 (providing evidence of Iraqi government camps that had trained Islamic terrorists); David E. Sanger, Bush Sees "Urgent Duty" to Pre-empt Attack by Iraq, N.Y. TIMES, Oct. 8, 2002, at A1 (reporting President Bush as building a lengthy, if circumstantial, case of Saddam Hussein's ties to al-Qaeda). But see James Risen \& Dexter Filkins, Qaeda Fighters Said to Return to Afghanistan, N.Y. TIMES, Sept. 10, 2002, at A1 (reporting that senior U.S. intelligence and law enforcement officials "say that they have found no evidence to prove that Iraq had any involvement in the Sept. 11 attacks"); David Stout, Bush Calls Iraqi Vow a Trick; Rumsfeld Urges Early Action, NEW YORK TIMES, New York (USA), (Sept. 18, 2002), at http://www.nytimes.com (on file with the North Carolina Law Review) (noting that the United States has not accused Iraq of having a role in the September 11 attacks, but that the Secretary of Defense has affirmed that any move to dislodge the Iraqi dictator should be thought of as an integral part of the campaign against terrorism, because Iraq and A-Qaeda are partners in terror) Kevin J Kelly, 'Fake Iraq-Africa Link That Drove America to War' THE EAST AFRICAN, Nairobi (Kenya), Mar. 31, 2003. Arguing that during a crucial four-month period leading up to the current war in Iraq, US and British officials falsely charged that
} 
intervention justifiable on the basis of pre-emptive or anticipatory self-defence, and hence providing a green light to proceed independently of Security Council approval. ${ }^{51}$ US national security strategy was adamant in its commitment not to hesitate to act alone, and increasingly chafed at UN control over the use of force against rogue states that present perceived security threats. ${ }^{52}$ The end game of this debate was cemented by President George Bush when he announced that "the policy of [his] government is the removal of Saddam [Hussein].,"53

President George W. Bush Jr. spent months making a case for waging war against Iraq with a confusing jumble of arguments that were long on rhetoric and short on substance. His favourite arguments however were invocation of a sweeping new foreign policy based on the right of the United States to pre-emptive self-defence, the need to punish Iraq for not complying with the Security Council resolutions to which it agreed in exchange for an end to the Gulf War and the need for massive retaliation. US President George Bush seemed unsure of the exact contours of his doctrine tying up pre-emptive strikes with retaliation (this the author avers falls under the rubric of peace time reprisal).

Deterrence--the promise of massive retaliation against nations--means nothing against shadowy terrorist networks with no nation or citizen to defend.... Containment is not possible when unbalanced

\footnotetext{
Saddam Hussein's government had tried to buy large quantities of uranium for nuclear weapons from an African country. With President George W. Bush, including this in his annual State of the Union address on 29 January 2002). The article can be accessed at the following URL <http://www.nationaudio.com/News/EastAfrican/current/Regional/Regional3103200359.html> (last visited May 2, 2003). The doubts and skepticism have been finally laid to rest in favour of the skeptics by the admission of no links between the September 11 attacks and Iraq by none other than US President George Bush and senior government officials. See infra note 56.

${ }^{51}$ See Oliver Moore, U.S. Troops Going Cave-to-Cave in Tora Bora, GLOBE \& MAIL (Toronto) (Dec. 18, 2001), at http://www.globeandmail.com (on file with the North Carolina Law Review) ("Asked whether the United States might need a new resolution from the United Nations Security Council to strike suspected terrorist targets outside Afghanistan, [Defense Secretary Rumsfeld] said: 'Nothing is needed by way of additional authorization. Every country has the right to self-defense." "); Steven R. Weisman, U.S and France Near Deal on Iraq Attack, N.Y. TIMES, Oct. 30, 2002, at A1 ("American officials made clear that the United States would reserve the right to lead a military action against Iraq if Iraq continued to block inspections, even if the Security Council did not give its approval.").

${ }^{52}$ President George W. Bush, The National Security Strategy of the United States of America, 15-16 (Sept. 17, 2002), at http:// www.whitehouse.gov/nsc/nss.pdf (last visited Aug. 2, 2003); A.P. NEWSWIRES, Sept. 20, 2002 , available at WESTLAW, Newswires.

${ }^{53}$ Allies Discuss Terrorism and the Middle East: Bush and Blair on Policy, N.Y. TIMES, Apr. 7, 2002 , at A14.
} 
dictators with weapons of mass destruction can deliver those weapons or missiles or secretly provide them to terrorist allies ... If we wait for threats to fully materialize, we will have waited for too long ... In the world we have entered, the only path to safety is the path of action. And this nation will act. ${ }^{54}$ [Emphasis added]

Though the more modest argument of retaliation may have been the strongest, nonetheless his doctrine was articulated more firmly in favour of anticipatory self-defence three months later. The National Security Strategy document, issued by President Bush in September 2002, asserted that:

For centuries, international law recognised that nations need not suffer an attack before they can lawfully take action to defend themselves against forces that present an imminent danger of attack. Legal scholars and international jurists often conditioned the legitimacy of pre-emption on the existence of an imminent threat--most often a visible mobilization of armies, navies, and air forces preparing to attack...

The United States has long maintained the option of pre-emptive actions to counter a sufficient threat to our national security. The greater the threat, the greater is the risk of inaction--and the more compelling the case for taking anticipatory action to defend ourselves, even if uncertainty remains as to the time and place of the enemy's attack. To forestall or prevent such hostile acts by our adversaries, the United States will, if necessary, act pre-emptively. ${ }^{55}$ [Emphasis added]

Interestingly, the National Security Strategy document did not refer to the longstanding policy as a principle but an option, in addition, the UN Charter, the centre point of the legal framework on the international use of force was not mentioned. Despite the delicate nature of US post-September 11 security strategy, it had Iraq firmly in its sights. The US and her allies continued to put forward what even then was regarded as faulty intelligence (now proven to be so $)^{56}$ in an attempt to link Iraq to the September 11 attacks. Secretary of State Colin Powell

\footnotetext{
${ }^{54}$ Westpoint Commencement Speech, supra note 1.

${ }^{55}$ Bush's National Security strategy, supra note 52.

${ }^{56}$ Dana Priest, U.S. Not Claiming Iraq Link to Terror, WASHINGTON POST, Washington D.C., (USA) Sept. 10, 2002, at A1 (reporting that CIA analysts are unable to validate reports that the Iraqi government has ties to $\mathrm{Al}$
} 
went as far as to admit that he was unaware of any "smoking gun" linking Iraq to September 11th. ${ }^{57}$ At least he was being honest from the outset considering that President Bush and other senior US government officials were to sheepishly admit months later after the war in Iraq what most states suspected all along--there was no link between Iraq and the September 11 attacks. ${ }^{58}$ Before the war though, despite international and domestic scepticism, the hawkish Bush administration was economical on truth having decided that the tragic events of September 11th had altered the context of the United States-Iraq confrontation. ${ }^{59}$ The resulting US shift to an aggressive Iraq policy forced it to advance rather dubious legal justifications for a full-scale invasion of Iraq. Relying on the new, multifaceted "Bush Doctrine," that advocates pre-emptive or preventive strikes against terrorists, states that support terrorists, and hostile states possessing weapons of mass destruction. The war against Iraq was to be the defining moment in the evolution of the "Bush doctrine" marking a growing coherence and confidence in the strategy of "offensive defence". Against a background of loud protests even from some of its traditional allies, the US launched military action in March 2003, its vastly technological superior army waged a highly organised technical war that impressed an otherwise angry international community, drove Saddam Hussein out of power, and occupied the country.

\footnotetext{
Qaeda); Walter Pincus, No Link Between Hijacker, Iraq Found, U.S. Says, WASHINGTON POST, Washington D.C., (USA), May 1, 2002, at A9; Kenneth M. Pollack, The Threatening Storm: The Case for Invading Iraqi xxixxii (2002); John Kampfner, BLAIR'S WARS, (2003); No 10 denies Straw had War Doubts, THE GUARDIAN, London, (UK) September 15, 2003 http://www.guardian.co.uk/uk_news/story/0,3604,1042511,00.html (last visited Sept. 18 2003); Matthew Tempest, Hoon Regrets 'Misunderstanding', THE GUARDIAN, London, (UK),September 11, 2003 http://politics.guardian.co.uk/iraq/story/0,12956,1039958,00.html (last visited Sept. 18 2003); Evidence 'Useless', THE OBSERVER, London, (UK) July 20, 2003, http://observer.guardian.co.uk/international/story/0,6903,1002061,00.html (last visited Sept. 18 2003)alleging that documents used to bolster the United States' claims that Iraq presented a nuclear threat were crudely-forged documents relating to Iraqi attempts to buy uranium from Niger.

${ }^{57}$ Bill Keller, The World According to Colin Powell, NEW YORK TIMES MAGAZINE, New York, (USA) Nov. 24,2001 , at 63.

${ }^{58}$ On September 17, 2003 President Bush stated that there was no evidence that Saddam Hussein was involved in the terrorist attacks of September 11, 2001--disputing an idea held by many Americans. This came a day after his hawkish Defense Secretary Donald Rumsfeld, said he had not seen any evidence hat Saddam was involved in the attacks. The National Security Adviser in support of the Bush and Rumsfeld sentiments saying: "We have never claimed that Saddam Hussein had either direction or control of 9/11." Bush: No evidence Saddam was involved in 9/11 Attacks, Sept. 17, 2003 http://edition.cnn.com/2003/US/09/17/sprj.irq.bush.ap/index.html (last visited Sep. 18, 2003).

${ }^{59}$ Kenneth M. Pollack, THE THREATENING STORM: THE CASE FOR INVADING IRAQ xxi-xxii (2002).
} 
However, the circumstances surrounding US intervention in Iraq differ fundamentally from those in Afghanistan. The United States has not conclusively proven that Al Qaeda maintained Iraqi training bases or that it received financial, logistic or military support from the Iraqi Government. The strategic and legal calculus for action in Iraq does not compare to that which motivated US action in Afghanistan in late 2001. What was different with the military action in Afghanistan as opposed to the military action in Iraq, was that the September 11 attacks drew favourable response to the use of force with America's right of self-defence being mentioned in the same breath as terrorist attacks but it is worth noting that the Security Council avoided speaking of "armed attack" as required by Article 51 of the UN Charter using instead the notion of "terrorist attack" without expressly linking this notion to Article 51 which is mentioned in a separate paragraph. ${ }^{60}$

Military action against Iraq has, not surprisingly split the international community and inflamed the world's major powers since it raises much debate both as a policy matter and as a legal matter. Considering that the use of armed force can only be justified under international law when used in self-defence, can the United States go beyond the rhetoric and actually carry the War on Terror to those rogue nations who are identified so closely as supporters and sponsors of terrorist activities, but have not actually physically engaged in an act of aggression against the United States? $?^{61}$ The convergence of international terrorism and weapons of mass destruction presents a grave threat to international peace, security, and prosperity by threatening the survival of entire nations. This threat multiplies exponentially when governments foster and encourage these dual scourges. What is disturbing about the US stance is the fact that an old problem in contemporary international law--anticipatory self-defence--is being touted as an appropriate vehicle in the war against international terrorism yet the general

\footnotetext{
${ }^{60}$ See Security Council Resolution 1368 adopted 12 September 2001 during the Council's $4370^{\text {th }}$ meeting. Text of the resolution can be accessed at the following URL <http://www.un.org/Docs/scres/2001/sc2001.htm>.

${ }^{61}$ Jeffrey F. Addicott, Legal and Policy Implications for a New Era: The "War on Terror, 4 SCHOLAR 209 (2002).
} 
view is that the "armed attack" requirement in Article 51 of the UN Charter superseded any pre-existing right of anticipatory action. ${ }^{62}$

The old truism, that international law is not a suicide pact, is forceful in "an age of uniquely destructive weaponry." ${ }^{63}$ Nevertheless strategically, there is little precedent for a major US military offensive against a state that has not proximately used force against US interests. Legally, while a number of legitimate justifications might permit the use of force, the international legal system does not currently provide such an outlet. An appropriate international law doctrine, under which the United States could execute the military campaign it recently successfully launched against Iraq, does not currently exist. But that lacuna was seemingly plugged with the "Bush Doctrine" that advocates pre-emptive strikes against rogue states and /or entities involved in terrorism. To put it in more staid phraseology, the preemptive strikes are premised on a right of anticipatory self-defence. The so-called "Bush Doctrine" articulates a new rule of international law that seeks to bring to life the doctrine of anticipatory self-defence as an appropriate means through which to combat terrorism (including states that actively support terrorism or that are themselves terror states in the sense of acquiring and stockpiling weapons of mass destruction).

Regardless of the existence of Iraqi connections to the September 11 attacks, the United States, citing Iraq's capacity to use weapons of mass destruction, asserts that self-defence legitimises the anticipatory intervention carried out against Iraq. ${ }^{64}$ Self-defence, it was suggested, also

\footnotetext{
${ }^{62}$ See the discussion in Part V of this Article.

${ }^{63}$ Louis R. Beres, The Permissibility of State-Sponsored Assassination During Peace and War, 5 TEMPLE INT'L \& COMP. L.J. 231, 239 (1992).

${ }^{64}$ Traditionally, anticipatory or preemptive self-defense has not been favored under international law. See Michael Byers, Terrorism, the Use of Force and International Law after 11 September, 51 INT'L \& COMP. L.Q. 410,402 (2002). However, the notion of preemptive "counter-proliferation" forms an important part of the new U.S. national security strategy. See Bush's National Security Strategy, supra note 52.
} 
fuels the need for internal "regime change" in Iraq and US support of such change. ${ }^{65}$ Without waiting for the UN Security Council to declare Iraq in breach of Security Council Resolution 1441 thus a threat to international peace and security for which the Council could then explicitly authorize military intervention, ${ }^{66}$ the US and its Allies proceeded with military action against Iraq premised on pre-emptive or anticipatory self-defence. This course of action viewed in the background of the more reasoned arguments by the US extends self-defence to a preemptive or anticipatory form. Although the legality of anticipatory self-defence is to be assessed in its own right, such legality may be facilitated by the changes to self-defence prompted by the September 11 attacks. In this regard, state practice may have set the tone for the legitimacy of anticipatory self-defence, although it is yet unclear whether state practice supports the operationalisation of such self-defence through the use of force against Iraq.

"International law tries mightily to limit the ability of nation-states to use military force against one another. While it has not successfully eliminated international military conflict, states nonetheless strive to couch military actions in terms justifiable under international law."67 While the United States has several possible legal arguments to support military intervention in Iraq, these arguments do not articulate the underlying paradigm-shift that US action against Iraq constitutes. ${ }^{68}$ Even if the United States can establish that the Hussein regime actively or tacitly supported international terrorism and acquired and stockpiled weapons of mass

\footnotetext{
${ }^{65}$ The United States affirmed it would provide "lethal assistance" in the form of military training and arms to Iraqi opposition volunteers and Kurdish fighters in Iraq. Patrick E. Tyler, U.S. and Britain Drafting Resolution to Impose Deadline on Iraq, NEW YORK TIMES, New York, (USA) Sept. 26, 2002, at A14; Julia Preston \& Eric Schmitt, U.S.-French Split on Iraq Deepens, NEW YORK TIMES, New York, (USA) Oct. 15, 2002, at A1 (reporting that the CIA has begun covert operations in the Kurdish area of northern Iraq with a view to fomenting an uprising in Iraq).

${ }^{66}$ UN Charter, arts. 39, 42. A plain reading of Resolution 1441, supra note 49, suggests another Security Council meeting in the event of an Iraqi breach, at least to discuss the inspectors' report, at which point the use of force could be authorized. On the other hand, the use of fuzzy and ambiguous language could be read as supporting the notion that the Security Council is allowing individual states greater interpretive latitude in deciding when force can be used.

${ }^{67}$ Christopher Clarke Posteraro, Intervention in Iraq: Towards A Doctrine of Anticipatory Counter-Terrorism, Counter-Proliferation Intervention 15 FLA. J. INT'L L. 151, 155 (2002). See also generally Louis Henkin, THE USE OF FORCE: LAW AND U.S. POLICY, IN RIGHT V. MIGHT 39-40 (1991).

${ }^{68}$ Posteraro, id, at 151.
} 
destruction (unlikely), the reliance on anticipatory self-defence resurrects a problem in contemporary international law on the use of force with its echoes of the supposedly obsolete right of self-preservation that fell into disuse in the early part of the $20^{\text {th }}$ century with the prohibition of war and the legal demarcation of the limits of the right to self-defence.

\section{Anticipatory Self-Defence: Background}

The right of self-defence by forestalling an attack is not new. It was well established in classical international law. In 1625, Hugo Grotius, whom John Bassett Moore calls "the most illustrious of the great philosophical jurists," and who is universally recognized as the Father of International Law, ${ }^{69}$ in his seminal work The Law of War and Peace, indicated that self defence is to be permitted not only after an attack has already been suffered, but also in advance, where "... the deed may be anticipated." ${ }^{, 70}$ Or as he said a bit later on in the text: "It be lawful to kill him who is preparing to kill ..."71 About a century and a quarter later, another famous publicist Emmerich de Vattel in his famous text of 1758 known as The Law of Nations, affirmed that "The safest plan is to prevent evil," and that to do so a nation may even "anticipate the other's design ..."72

Historically the law of self-defence was bound up with the amorphous right of selfpreservation. The right of self-preservation was seen as preceding and underlying every other obligation. It was thought that all treaties were subordinated and subject to this basic and inherent right. It was implied, and read into, every treaty and contract, anything to the contrary said notwithstanding. This primary right could not be lost or bargained away; it was

\footnotetext{
${ }^{69}$ See OPPEINHEIM, supra note 9.

${ }^{70}$ GROTIUS, supra note 10 , Bk II.

${ }^{71} \mathrm{Id}$.

${ }^{72}$ EMMERICH DE VATTEL, THE LAW OF NATIONS, OR, PRINCIPLES OF THE LAW OF NATURE, APPLIED TO THE CONDUCT AND AFFAIRS OF NATIONS AND SOVEREIGNS (J Chitty, Trans, $7^{\text {th }}$ ed, 1849).
} 
unalienable. In the $19^{\text {th }}$ century, anticipatory self-defence was still very much a topical issue. In 1861, the English jurist Travers Twiss opined that that:

Of the primary or absolute rights of a nation the most essential, and as it were, the cardinal right, upon which all others hinge, is that of self-preservation. This right necessarily involves, as subordinate rights, all other rights which are essential as means to secure this principal end. ${ }^{73}$

With regard to the "right of anticipating attack," the same author stated that:

\begin{abstract}
When the safety of the State is at stake, the right of self-preservation may warrant a nation in extending the precautionary measures beyond the limits of its own dominions, and even in trespassing with that object on a neighbour's territory. As the right of self-preservation is prior and paramount to the right of dominion and property, in the case of individuals, so the right of self-preservation is prior and paramount to the right of territorial inviolability in the case of nations, and if ever these rights conflict, the former is entitled to prevail within the limits of the necessity of the case. ${ }^{74}$
\end{abstract}

Later in the $19^{\text {th }}$ century, a leading international jurist Sir Robert Phillimore asserted that:

The right of self-preservation is the first law of nations, as it is of individuals. . . It may happen that the same right may warrant her in extending precautionary measures without these limits, and even in transgressing the borders of her neighbour's territory. For International Law considers the 'Right of Self-Preservation' as prior and paramount to that of Territorial Inviolability, and, where they conflict, justifies the maintenance of the former at the expense of the latter right. ${ }^{75}$

Essentially then, the right of self-preservation is called into being whenever the corporate existence of a state is menaced and corresponds to the individual right of self-defence. The danger may be internal, as in case of insurrection or rebellion, or external, as in case of invasion, either real or threatened. The right of self-preservation is the first law of nations, as it is of individuals. A society which is not in condition to repel aggression from without is wanting in its principal duty to its members of which it is composed, and to the chief end of its institution. All means which do not affect the independence of other nations are lawful to this end. No nation has a right to prescribe to another what these means shall be, or to require any account of her conduct in this respect.

\footnotetext{
73 TRAVERS TWISS, THE LAW OF NATIONS IN TIME OF PEACE, page 144, Section 99 (1861).

${ }^{74}$ Id. Section 102, page 149.

${ }^{75}$ ROBERT PHILLIMORE, COMMENTARIES UPON INTERNATIONAL LAW, Chap. 10 (CCXI) (1879-89).
} 
The right of self-preservation had always been capacious enough to justify action beyond what was necessary for the maintenance of the integrity of territorial domain of a state. Commenting on the right of self-preservation and the occasional necessity to undertake anticipatory action in defence of the State and its interest, in 1880 William Edward Hall in his masterpiece, $A$ Treatise on International Law asserted that:

\begin{abstract}
The right of self-preservation in some cases justifies commissions of acts of violence against a friendly or neutral state, when from its position and resources it is capable of being made use of to dangerous effects by an enemy, when there is a known intention on his part so to make use of it, and when, if he is not forestalled, it is almost certain that he will succeed, either through the helplessness of the country. or by means of intrigues with a party within it. ${ }^{76}$
\end{abstract}

International legal scholars generally agree that customary international law recognized a right to anticipatory self-defence. ${ }^{77}$ The most often cited articulation of those customary standards is found in the words of then-Secretary of State Daniel Webster from the Caroline incident. ${ }^{78}$

\title{
B. The Caroline Incident
}

Where it is understood as "anticipatory self-defence," the customary right to pre-empt has its modern origins in what is known as the Caroline incident. The Caroline case of 1837 established the modern fundamental Anglo-American concept of self-defence. ${ }^{79}$ Here, during the unsuccessful rebellion of 1837 in Upper Canada against British rule, it was established that the serious threat of armed attack may justify militarily defensive action. In an exchange of diplomatic notes between the governments of the United States and Great Britain, then US Secretary of State Daniel Webster outlined a framework for self-defence which did not require

\footnotetext{
${ }^{76}$ WILLIAM EDWARD HALL, A TREATISE ON INTERNATIONAL LAW, 273 (1884).

77 ANTHONY CLARK AREND \& ROBERT J. BECK, INTERNATIONAL LAW \& THE USE OF FORCE 72 (1993).

${ }^{78}$ See Destruction of the Caroline, 2 Moore, A DIGEST OF INTERNATIONAL LAW § 217 (1906).

${ }^{79}$ Byard Q. Clemmons \& Gary D. Brown, Rethinking International Self-Defense: The United Nations' Emerging Role, 45 NAVAL L. REV. 217, 220 (1998).
} 
a prior attack. Military response to a threat was judged permissible so long as the danger posed was "instant, overwhelming, leaving no choice of means and no moment of deliberation." 80

"Until the Caroline case, self-defence was a political justification for what, from a legal perspective, were ordinary acts of war. The positivist international law of the 19th century rejected natural law distinctions between just and unjust wars. The Caroline Case did nothing to prevent aggression, but it did draw a legal distinction between war and self-defence. ${ }^{, 81}$ As long as the act being defended against was not itself an act of war, peace would be maintained a matter of considerable importance to relatively weak countries, as the United States then was. The customary right of self-defence involved the assumption that the force used must be proportionate to the threat. The formula used, by Webster in relation to the Caroline incident has attracted writers by virtue of his insistence that self-defence must involve "nothing unreasonable or excessive; since the act, justified by the necessity of self-defence, must be limited by that necessity, and kept clearly within it." 82 The Webster correspondence in reality merely stated a right of self-defence which had a more limited application than the vague right of self-preservation and the broad and political concept of self-defence found in nineteenth century thought and practice. Evidently the legal concept of self-defence comprehended proportionality as a special requirement in the law of nations representing an attempt to create the necessary distinction between self-defence and self-help in reaction to an historical tendency to confuse them.

The Caroline criteria of necessity and proportionality became widely accepted as customary international law-an unwritten body of rules formed from the behaviour and opinions of states.

\footnotetext{
${ }^{80} I d$. at 221 (internal quotations omitted) (quoting MYRES S. MCDOUGAL \& FLORENTINO P. FELICIANO, LAW AND MINIMUM WORLD PUBLIC ORDER 217 (1961)).

${ }^{81}$ Michael Byers, Jumping the Gun, 24 LONDON REVIEW OF BOOKS 14, Jan. 25 (2002).

${ }^{82}$ Caroline Incident, supra note 78.
} 
However, the period before the advent of the League remained of a diffuse character reflecting the lack of the legal regulation of the use of force. A state when exposed to a grave, imminent danger, was fully justified in committing any action liable to avert that danger, even if, under normal conditions, such action would constitute a wrong and a violation of international law. It can be concluded that customary law permitted anticipatory action in face of imminent danger. There can be little doubt that the right of self-preservation and the doctrine of necessity comprehended anticipatory action. The Caroline doctrine permitted preventive action in a context in which self-defence was equated with self-preservation. The particular fault of this seeming customary rule was that it provided no clear guidance as to the determination of cases in which anticipatory acts of force may be justified. Despite the Webster formula, the Caroline case was primarily verbal lacking any well-established state practice to prop it up firmly. The Caroline doctrine was very much in tune with the general thinking of the $19^{\text {th }}$ century as reflected in the works of leading jurists of the day some of whose positions have been mentioned above. The acceptance of the notion of anticipatory self-defence carried over into the 20th century. In the opening years of the century, John Westlake, a leading international law scholar reaffirmed the right of self-preservation and its collorary, the right to anticipatory self-defence. $^{83}$

About a decade after Westlake's reaffirmation of the right to self-defence, the First World War broke out. The scale of death and destruction and its terrible consequences for victim and aggressor alike served to convinced statesmen that war was no longer a profitable enterprise. In the face of the realities of modern warfare and the consequences of total war, the need for

${ }^{83}$ He noted that:

A State may defend itself, by preventive means if in its conscientious judgment necessary, against attack by another State, threat of attack, or preparations or other conduct from which an intention to attack may reasonably be apprehended. 
constraints on military aggression was obvious. A first effort was made in 1919, when the League of Nations Covenant was adopted at Versailles. It was during the era of the League that the concept of aggression (as an unlawful use of force) ${ }^{84}$ appeared as the right of selfpreservation fell into disrepute. ${ }^{85}$ Under the Covenant the Council of the League could issue recommendations to states in danger of going to war. If the Council failed to agree, however, the disputing parties were free to take whatever action they considered necessary for the maintenance of right and justice. The League lacked the capacity to enforce decisions, with any hope that it would co-ordinate enforcement action by its members disappearing when the US Senate rejected the Covenant in 1920. The legal developments of the period of the League had the result that, while the right of self-preservation no longer existed in its classical form, some of its content was preserved. This residual right was referred to as that of self-defence or legitimate defence. It was understood that this right of legitimate defence was subject to objective and legal determination and that it was confined to reaction to immediate danger to the physical integrity of the state itself. Attempts by governments to reserve the right of determining the existence of a necessity for self-defence including pre-emptive strikes did not meet with success. The acceptance of the existence of a right to self-defence which was essentially a legally defined right was not in fact accompanied by any precise definition of the content of the right.

The move towards the prohibition of war as an instrument of national policy and recognition of the right of self-defence as a legal right was capped by the Kellogg-Briand Pact in $1928 .{ }^{86}$ The Pact, which was eventually ratified by 62 states, made an exception for self-defence, but failed to define it - with the result that the customary criteria set out in the Caroline case remained the

\footnotetext{
${ }^{84}$ BROWNLIE, supra note 7, at 351-352.

${ }^{85}$ Aggression was synonymous with an armed attack, the unlawful use of force, which justified action in selfdefense. The assertion that the right of self-defense justified preventive action in the face of potential threats to the interests of states was seen as a relic of the vague and obsolete right of self-preservation or the doctrine of selfhelp which the war had helped credit.

${ }^{86}$ Kellogg-Briand Pact, supra note 16.
} 
only legal bases for the use of force in international affairs. Strong on principle but lacking an enforcement mechanism, the Pact had little practical effect. ${ }^{87}$ Despite the significant advances in embedding self-defence in international law, its more problematic aspect-anticipatory selfdefence still appeared to be a doctrine that was far from dead. The outbreak of the Second World War witnessed claims and counterclaims by warring states surfacing based primarily on an exercise of self-defence and frequently an exercise of anticipatory self-defence. The issue of anticipatory self-defence arose at the trials before the international military tribunals at Nuremberg and Tokyo set up to prosecute among other crimes-the crime of aggression. At Nuremberg, defence counsel argued before the international military tribunal that the German attack on the Soviet Union had merely anticipated a Soviet attack. ${ }^{88}$ The Tribunal seemed to implicitly accept the legality of anticipatory action since it dismissed this argument not on the ground of law but rather in relation to the facts noting that:

It was contended for the defendants that the attack upon the USSR was justified because the Soviet Union was contemplating an attack upon Germany, and making preparations to that end. It is impossible to believe that this view was ever honestly entertained. ${ }^{89}$

In the Far East, the International Military Tribunal sitting in Tokyo considered a similar argument. The Netherlands had declared war on Japan on 8 December 1941, before any attack had occurred against the Netherlands East Indies. However, Japan had laid plans to attack the Netherlands East Indies on that date. In this instance, the Tribunal rejected the view that the Japanese action was lawful by virtue of the Netherlands declaration of war. ${ }^{90}$ Unlike the Nuremberg Tribunal, the Tokyo Tribunal did bring into play the issue of law with regard to the

\footnotetext{
${ }^{87}$ The pact never made a meaningful contribution to international order, although it was invoked in 1929 with some success, when China and the USSR reached a tense moment over possession of the Chinese Eastern RR in Manchuria. Ultimately, however, the pact proved to be meaningless, especially with the practice of waging undeclared wars in the 1930s (e.g., the Japanese invasion of Manchuria in 1931, the Italian invasion of Ethiopia in 1935, and the German occupation of Austria in 1938). See generally R. H. FERRELL, PEACE IN THEIR TIME (1952, repr. 1968).

${ }^{88}$ TRIAL OF MAJOR WAR CRIMINALS (H.M.S.O.), Part 18 p. 160 (Horn); Part 19 pp 134-5 (Exner).

${ }^{89}$ NUREMBERG JUDGMENT, Cmd. 6964, 35.

${ }^{90}$ CASES ON UNITED NATIONS LAW 915 (1967) (Louis B Sohn ed.).
} 
claim of anticipatory self-defence. ${ }^{91}$

Amidst the backdrop of the Nuremberg and Tokyo trials, in 1945, a new world order was seemingly inaugurated by the coming into force of the UN Charter. The Charter sought to craft and guarantee a new system of international peace and security. The drafters of the Charter were hardly naïve. Having the lessons of the League's failure in mind, they recognized that the UN could be imperilled if powerful states were threatened with collective action. They granted permanent membership of the Security Council and a veto on its actions to Britain, China, France, the Soviet Union and the US. Knowing that the Council could never respond promptly to every act of aggression, they also included an exception for self-defence. But in addition to the two restrictions of necessity and proportionality recognized under customary law in relation to self-defence, three new restrictions were introduced: a state could act in self-defence only if subject to an "armed attack", acts of self-defence had to be reported immediately to the Council, and the right to respond ended as soon as the Council took action. This was a constitutional moment in international affairs: an anarchic world of self-help and temporary alliances was being transformed into a nascent system of governance. To link self-defence with a "right of self-protection" was no longer admissible. Why else did the League Covenant and United Nations Charter, seek to establish the illegality of self-help and reiterate the obligation to settle disputes peacefully?

It is also of significance to note that that in heydays of anticipatory self-defence, states also dealt with each other on the basis of reciprocity. There were no supranational institutions to make or enforce international law. States had the right to retaliate against states that failed to honour bilateral or multilateral arrangements through use of reprisals (retaliation by force) in ways that would otherwise have been considered illegal. "In the absence of a supranational

\footnotetext{
${ }^{91}$ See BROWNLIE, supra note 7, at 258.
} 
authority, this form of self-help was a way for states to get compensation for their losses, punish their offenders, and deter future violations." 92

In contemporary times, claims of "pre-emptive" action have often been mentioned in the same breath as retaliation (this the author avers refers to the use of peacetime reprisal rather than simply retaliation). ${ }^{93}$ Reprisal, like self-defence is a self-help remedy in reaction to an unjust action by another state. There are certain preconditions that are common for both self-defence and reprisal. These requirements boil down to necessity and proportionality. The terms have the same definition for reprisal as they have for self-defence. Considering that the discussion in Parts IV and V of the Article involves the use of reprisals, the Article turns next to consider briefly reprisals in international law in the next section.

\section{B. An Eye for an Eye: Peacetime Reprisals (Retaliatory Attacks)}

The origin of modern international law concerning reprisals may be found in the medieval practice of private reprisals. These were acts of retaliation authorized by the sovereign upon the issuance of "letters of marque and reprisals" to redress wrongs committed by the citizens of one state against those of another. ${ }^{94}$

\footnotetext{
${ }^{92}$ Stephanie Giry, New World, old Law: Would a unilateral Strike against Iraq Ever have Been Legal, 2003-FEB, LEGAL AFFAIRS 21.

${ }^{93}$ See e.g. President Reagan's statements after bombing military targets in Tripoli and Benghazi, Libya on April 15, 1986 in response to an April 5, 1986 bombing of a West German discotheque in which two Americans died and 154 persons were injured. Speech by Ronald Reagan, International Terrorism, U.S. Dep't of St. Bureau of Pub. Affairs Spec.Rep. No. 24, at 1 (1986); White House statement of Apr. 14, 1986; President George W. Bush's Westpoint Commencement Speech, supra note 1.

${ }_{93}$ Bush's National Security Strategy, supra note 52.
}

When a subject of one feudal state considered himself wronged by a subject of another state, he was entitled to raise his grievance before his own sovereign. Upon a satisfactory showing that a wrong had been committed against him by the other party and that he had unsuccessfully sought redress in the territory of the wrongdoer, his own sovereign could issue a "Letter of Marque and Reprisal." The Letter of Marque and Reprisal only permitted seizure of a specific amount of property, normally determined by the extent of the original injury suffered. This is the origin of the notion of "proportionality," which is a fundamental aspect of today's concept of reprisal. 
"In the 16th and 17 th centuries this practice was so frequently employed that it resulted in a series of 'wars' of reprisal, in which seizures aimed at disruption of enemy trade, at provoking a foe to full scale hostilities, or merely at filling the interval between war and peace." ${ }^{\text {"95 }}$ As might be expected, any pretext would be advanced to satisfy the previously stringent requirement of unredressed injury, as individual justice became subordinated to political interests. ${ }^{96}$ Leaders were quick to recognize the advantage that limited acts of coercion would play in international relations between the employment of armed force limited to a single form and the comprehensive use of armed force amounting to war. ${ }^{97}$

By the 19th Century, peacetime reprisals came to include such measures of minor coercion, as pacific blockade and military occupation. In the $20^{\text {th }}$ century, peacetime reprisals gained international recognition. In the Naulilaa $\mathrm{Case}^{98}$ an arbitral panel adjudicating a claim in which Portugal sought reparation for illegal reprisals established the criteria for lawful reprisals. These are:

1. A prior violation of international law by the offending state;

2. a request for redress of the injury which has been refused or ignored by the offending state; and

3. an action which is proportionate to the original injury and which ceases once reparation has been obtained. $^{99}$

The principal objective of a reprisal is not to punish (although that may be an element) but rather to compel a change in state policy or obtain reparation for injury.

\footnotetext{
${ }^{95}$ Michael Fanklin Lohr, Legal Analysis of US Military Responses to State-Sponsored Terrorism, 34 NAVLA L. REV. Review 1, 27-28 (1985).

${ }^{96}$ E. COLBERT, RETALIATION IN INTERNATIONAL LAW 47 (1948).

${ }^{97}$ F. KALSHOVEN, BELLIGERENT REPRISALS 1 (1971). 3.

${ }^{98}$ Naulilaa Case (Port. v. Ger.) 2 R. Int'l Arb. Awards 1011 (1928). These factors, as articulated include: (1) The German reprisal was not preceded by sufficient legal action; (2) the German officials did not precede their action with an attempted peaceful redress for the injury; and (3) the actions employed by the German officials were disproportionate to the original injury. Id. at 1026.

${ }^{99} I d$.
} 
As it has evolved from the Naulilaa Case, customary international law sets forth two prerequisites that must be accommodated before a state may institute an armed reprisal during peacetime: determination of a breach by a state of an internationally recognized obligation. "This is particularly important in considering reprisals against states alleged to be sponsoring international terrorism." ${ }^{100}$ Given that an international delinquency has occurred and that a responsible state has been identified, the second prerequisite is the absence of redress; that is, an unsuccessful demand by the injured state upon the offending state for cessation of the illegality, for redress, or for both. After redress has been denied the customary international law requires that the injured state effect its reprisal subject to the requirement that its action be proportionate to the original injury and that the reprisal cease once reparation has been obtained. $^{101}$

In the words of Michael F Lohr:

\begin{abstract}
Under customary law, the reprisal is not authorized by any previous authoritative community decision; neither is it an act of self-defence as its aim is not directly to repel the blow of the delinquent state's preceding act. Its purpose is to coerce the state subject to the reprisal to change its policy and bring it into line with the requirements of international law. This function of law enforcement qualifies the reprisal as a sanction under international law. Finally, the reprisal must respect the conditions and limits laid down in international law for justifiable recourse to reprisals, that is, peaceful attempts of redress have been tried and failed, and proportionality in responding is observed. ${ }^{102}$
\end{abstract}

After the Second World War, armed reprisals were officially banned. The UN Charter stated the rule prohibiting aggression that still applies today: "All members shall refrain in their international relations from the threat or use of force against the territorial integrity or political independence of any state, or in any other manner inconsistent with the purposes of the United Nations." "The Charter granted the Security Council a quasi-monopoly on force, limited

\footnotetext{
${ }^{100}$ Lohr, supra note 95 , at 30.

${ }^{101}$ Naulilaa Case, supra note 198, at 1026

${ }^{102}$ Lohr, supra note 95 , at 31-32.

${ }^{103}$ UN Charter, art 2(4).
} 
only by the right of states to act in self-defence in response to "an armed attack." In the event of a provocation short of an armed attack, states were expected to trust the Security Council to respond properly--with economic sanctions or force or whatever other measure it deemed appropriate. $" 104$

Considering that Articles 2(4) and 51 of the UN Charter seek to protect the primary interest in freedom from aggression and the right of self-defence as a sanction, some commentators have concluded that reprisals are illegal under the Charter. This view is set forth by Ian Brownlie: "The provisions of the Charter relating to the peaceful settlement of disputes and non-resort to the use of force are universally regarded as prohibiting reprisals which involve the use of force."

The Security Council expressed its view of the status of reprisals in 1964 when it censured Great Britain for carrying out a reprisal against the Yemeni town of. By a vote of 9-0, with two abstentions, the Security Council determined that it "[c]ondemns reprisals as incompatible with the purposes and principles of the United Nations."106 The Council's rationale was that the members of the United Nations contracted not to use force to achieve solutions to international controversies. $^{107}$

Michael F Lohr however observes that:

There is, however, a contrary view that the Charter does not prohibit forcible self-help, i.e., reprisals entirely. An argument can be made that resorts to reprisals are both legal and desirable under the Charter. First, Security Council practice implies the recognition of the legitimacy of some type of reasonable reprisal. There is however an inconsistency between the Security Council's alleged principle

\footnotetext{
${ }^{104}$ Giry, supra note 92, at 21.

105 BROWNLIE, INTERNATIONAL LAW AND THE USE OF FORCE BY STATES 255- 57 (1963).281.

${ }^{106}$ Richard Falk, The Beirut Raid and the International Law of Retaliation, 63 AM. J. INT'L L. 415, 429 and n. 37 (1969).

${ }^{107}$ McDougal \& Feliciano, Legal Regulation of the Right to International Coercion, 68 YALE L. J. 1063-64 (1958).
} 
of the illegality of all armed reprisals and the Council's practice in not condemning a particular reprisals because it appeared reasonable. A practice of condemning only unreasonable or disproportionate reprisals is, in effect, an affirmation of the right of states to resort to reasonable reprisals. ${ }^{108}$

Though reprisals share many of the attributes of "anticipatory self-defence" as a form of forcible self-help, it is pointed out that The Declaration on Principles of International Law concerning Friendly Relations and Co-operation among States in accordance with the Charter of the United Nations ${ }^{109}$ seems to suggest that members of the United Nations, including the United States, have legally renounced the use of peacetime reprisals. However, the US stance of "passive, reactive and patient defence response" 110 to terrorism of the early 1970s which lasted to the spring of 1984 shifted to a "no compromise" and very proactive approach-the "Reagan Doctrine". ${ }^{111}$ Subsequent US Presidents have had recourse to the swift, effective retribution tenet that underlies the doctrine often wrapping it up together with the "right of anticipatory self-defence".

Having discussed the notions of anticipatory self-defence and reprisals, the Article now turns to discuss the UN Charter regime on the use of force and its relation to the tenets of the "Bush Doctrine". At the heart of the regime is Art. 2(4) whose significance has been emphasised by authors who label it "the corner stone of peace in the Charter""112 and "the heart of the United Nations' Charter basic rule of contemporary public international law". ${ }^{113}$ The use of force, rather than solely war, is prohibited. This prohibition is not confined to the actual use of force, but extends to the mere threat of force.

\footnotetext{
${ }^{108}$ Lohr, supra note 95 , at 32-33.

${ }^{109}$ G.A.Res. 2625, 25 UN GAOR Supp. (No. 28), UNDoc. A/8028 (1970).

${ }^{110}$ Shirlyce Manning, The United States' Response To International Air Safety, Dec.1995-Jan. 1996) 61 J. AIR L. \& COM 505, 519.

${ }^{111}$ CRELINSTEN \& SCHMID, supra note 40.

112 Douglas Eisner, Humanitarian Intervention in the Post-Cold War Era, 11 B. U. INT'L L. J. 195, 196 (1993); Bartram Brown, Humanitarian Intervention at a Crossroads, WM. \& MARY L. REV. 1683 (2000).

${ }^{113}$ Bartram Brown, id, n 56; Oscar Schachter, The Right of States to Use Armed Force, 82 MICH. L REV. 1620 (1984).
} 


\section{Self-Defence Under the UN Charter}

The prohibition of the use of force embodied in Art. 2(4) of the UN Charter not only proscribes war, but any use or threat of force in general. Apart from the, now obsolete, clauses concerning the former enemy states, the UN Charter contains only two exceptions to the prohibition of force, namely Security Council enforcement actions pursuant to Chapter VII, and the right to individual and collective self-defence laid down in Article 51. As the system of collective security has been of little practical significance, international legal practice since 1945, contrary to the intentions of the authors of the Charter, continues to be determined by the unilateral use of force by states. Yet in this respect the Charter provides in Article 51 for an exclusive regulation, allowing individual states the threat or use of force only under the conditions stipulated there. ${ }^{114}$ The right of self-defence laid down in Article 51 of the UN Charter, being the only exception to the prohibition of force of practical significance, is therefore the pivotal point upon which disputes concerning the lawfulness of the use of force in, inter-state relations usually concentrate. Commenting on the practical implications of

Article 51, Professor I Brownlie explains that:

[i]t is believed that the ordinary meaning of the phrase precludes action which is preventive in character. In this respect the French text is less equivocal than the English since its literal translation would read in a case where a United Nations Member is the object of an armed aggression. The Spanish text simply reads "en caso de ataque armado". There is no further clarification of the phrase to be gained from study of the travaux preparatoires. However, the discussions at San Francisco assumed that any permission for the unilateral use of force would be exceptional and would be secondary to the general prohibition in Article 2, paragraph 4. There was a presumption against self-help and even action in self-defence within Article 51 was made subject to control by the Security Council. In these circumstances the precision of Article 51 is explicable. ${ }^{115}$

\footnotetext{
${ }^{114}$ Article 51 of the Charter provides:
}

Nothing in the present Charter shall impair the inherent right of individual or collective self-defense if an armed attack occurs against a Member of the United Nations, until the Security Council has taken measures necessary to maintain international peace and security. Measures taken by Members in the exercise of this right of self-defense shall be immediately reported to the Security Council and shall not in anyway affect the authority and responsibility of the Security Council under the present Charter to take at any time such action as it deems necessary in order to maintain or restore international peace and security.

${ }^{115}$ BROWNLIE, supra note 7, at 275. 
The text of the UN Charter represents a conventional rejection of the just war theories of retribution. Article 2, paragraph 3 of the Charter requires states to settle disputes peacefully. Reprisals are illegal under international law because they are punitive, rather than legitimate, actions of self-defence. It would be difficult to conform acts of reprisal with the overriding dictate in the Charter that all disputes must be settled by peaceful means. Indeed, the use of reprisals represents a regression to the just war theory, which was abandoned in the seventeenth century. The purpose of international bodies such as the League of Nations and the United Nations was to limit the use of force in international matters and to provide a forum for the resolution of conflict in international matters so as to prevent the need for war. To permit reprisals would thwart the very goal to which states have committed themselves by membership in to the $\mathrm{UN}^{116}$

A major question is whether the right of self-defence under Article 51 is limited to cases of armed attack or whether there are other instances in which self- defence may be available under Article 51. A number of commentators argue that the right to use force in self-defence under Article 51 is not limited to cases of armed attack. ${ }^{117}$ As Professor G M Travalio observes,

[t]hese commentators generally argue that the intention of the drafters of the United Nations Charter was to incorporate into Article 51 all of the rights of self-defence that existed in customary international law at the time of the Charter In addition, the International Court of Justice in the Nicaragua Case, indicated that the right of self-defence in Article 51 simply recognized a pre-existing right of customary international law. ${ }^{118}$

\footnotetext{
${ }^{116}$ See Guy B. Roberts, Self-Help in Combating State-Sponsored Terrorism: Self-Defense and Peacetime Reprisals, 1987 CASE W. RES. L. REV. 286. In the case of Israel, however, the United States has sometimes insisted, before condemning a reprisal by Israel, that the terrorist act that prompted the reprisal also be condemned. See William O'Brien, Reprisals, Deterrence, and Self-Defense in Counterterror Operations, 30 VA. J. INT'L LAW 421, 433.

${ }^{117}$ See, e.g., Myres McDougal and Florentino P. Feliciano, Conditions and the Expectation of Necessity, in LAW AND MINIMUM WORLD PUBLIC ORDER 234-35 (1961).

${ }^{118}$ Gregory M. Travalio, Terrorism, International Law, and The Use of Military Force, 18 WIS. INT'L L.J. 145 (2000).
} 
Because the customary right of self-defence, so the argument goes, includes instances in addition to an armed attack, military force may be legally available as an option against terrorists even if an armed attack has not occurred. This view holds that the presence of an armed attack is one of the bases for the exercise of the right of self-defence under Article 51, but not the exclusive basis. ${ }^{119}$ Professor Oliver Schacter concisely states this position thus:

On one reading [of Article 51] this means that self-defence is limited to cases of armed attack. An alternative reading holds that since the article is silent as to the right of self-defence under customary law (which goes beyond cases of armed attack) it should not be construed by implication to eliminate that right ... It is therefore not implausible to interpret article 51 as leaving unimpaired the right of selfdefence as it existed prior to the Charter. ${ }^{120}$

A significant number of writers argue that an armed attack is the exclusive circumstance in which the use of armed force is sanctioned under Article $51 .{ }^{121}$ In fact, one commentator has gone so far as to state that "the leading opinion among scholars" is that the right of self-defence in Article 51 does not extend beyond armed attack. ${ }^{122}$ Furthermore, the International Court of Justice in Nicaragua Case clearly stated that the right of self-defence under Article 51 only accrues in the event of an armed attack. ${ }^{123}$ Also, it is a traditional requirement of self-defence that a triggering event justifying a military response have already occurred or at least be imminent. $^{124}$ Summing up these arguments, Professor G M Travalios concludes that

... it is generally believed that the right of self-defence, even if it extends beyond the "armed attack" of Article 51, does not permit the use of force to punish an aggressor after a threat has passed, nor does it

\footnotetext{
${ }^{119}$ See James Terry, Countering State-Sponsored Terrorism: A Law-Policy Analysis, 36 NAVAL L. REV. 159, 170 (1986); Oscar Schachter, International Law; the Right of States to Use Armed Force, 82 MICH. L. REV. 1620, 1633-34 (1984).

${ }^{120}$ Schachter, id. at 1633-34.

${ }^{121}$ See, e.g., YORAM DINSTEIN, WAR, AGGRESSION, AND SELF-DEFENCE 183 (2nd ed. 1994) (choice of words in Article 51 is deliberately restrictive; right of self-defense is limited to armed attack).

${ }^{122}$ Id. at 186. See Michael Lohr, Legal Analysis of U.S. Military Responses to State-Sponsored International Terrorism, 34 NAVAL L. REV. 1, 18 (1985) (referring to PHILLIP JESSUP, A MODERN LAW OF NATIONS 166 (1948) and LASSA OPPENHEIM, INTERNATIONAL LAW 156 (H. Lauterpact 7th ed.)).

${ }^{123}$ In para. 195 of its opinion, the Court said that the exercise of the right of self-defense by a state under Article 51 "is subject to the state concerned having been the victim of an armed attack." 1986 I.C.J. at 103.

124 See HILAIRE MCCOUBREY AND NIGEL D. WHITE, INTERNATIONAL LAW AND ARMED CONFLICT 91-92 (1992).
} 
permit the use of force to deter a less than imminent threat. The basis in international law for this limitation is the famous Caroline case. ${ }^{125}$

Apart from reference to phrases in Article 2(4) to which it is sought to give a restricted meaning, it can be argued that Article 51 and paragraph 4 of Article 2 were not intended to, and do not restrict the right of member states to use force in self-defence within the meaning of that concept to be found in the customary law. Article 51, it is said, refers merely to 'armed attack' because it was inserted for the particular purpose of clarifying the position of defence treaties which are concerned only with external attack, and being in this way specific it leaves the broader customary right, which is always implicitly reserved, intact. Professor D Bowett holds the view that Article 2, paragraph 4, left the right of self-defence unimpaired and that the right implicitly excepted was not confined to reaction to 'armed attack' within Article 51 but permitted the protection of certain substantive rights:

Action undertaken for the purpose of, and limited to, the defence of a State's political independence, territorial integrity, the lives and property of its nationals (and even to protect its economic independence) cannot by definition involve a threat or use of force 'against the territorial integrity or political 'independence' of any other state. ${ }^{126}$

If the right of self-defence extends beyond the "armed attack" of Article 51, there are, at the very least, serious hurdles that must be overcome before self-defence, as traditionally understood, can be used to justify attacks against terrorists or terrorist facilities located in another state. If the anticipated action by terrorists is not sufficiently imminent, the right to use force is not available for purposes of deterrence. ${ }^{127}$ Professor G M Travalio notes that:

... if past terrorist actions by a group are too remote in time, the response by force is likely to be characterized as an illegal reprisal. It appears that if a right to use force in self-defence exists apart from

\footnotetext{
${ }^{125}$ Travalio, supra note 118 , at 162 .

${ }^{126}$ BOWETT, supra note 31 , at 188-9.

${ }^{127}$ Terry, supra note 119 , at 171 . In this article Lt. Col. Terry makes the point that given the rapid delivery capabilities of terrorist organizations, it is unrealistic to require that a state wait until an attack is imminent before responding. See id. The Israelis used similar arguments to justify their attack on the Iraqi nuclear facility at Osirak and these arguments were rejected by the United Nations and the world community. See O'Brien, supra note 70, at $450-451$.
} 
an armed attack, it is a right that presents a very narrow window of opportunity. In fact, this window of opportunity, under the traditional criteria for self-defence, will almost never exist in the context of terrorist attacks. The traditional requirements for self-defence are simply too restrictive to reasonably respond to the threat posed by international terrorism. ${ }^{128}$

Perhaps that is why the US saw the use of military action to remove the threat of chemical, biological and nuclear proliferation in Iraq as a strategic imperative arguing rather strongly that the risk of inaction in the face of such a threat is intolerable. In any case the decision to attack was done over the loud objections of other major powers and many international scholars who were worried by the effect of failure by the US to secure a Security Council mandate. Perhaps the answers to the headstrong stance by the US lie in C C Posteraro's observation that:

Legality becomes clear once [a] doctrine has become "authoritative state practice." The authoritativeness of a rule is determined by examining "official and unofficial communications by decision-making elites." ... State practice is the measure of control a given doctrine exerts on state behaviour. Put simply, "the rule is controlling if international actors comply with the rule."... Justice need not operate through statutes, charters or custom. The NATO intervention in Kosovo proved this to much of the world ... State practice is, in the long term, the ultimate arbiter of what international law is. It is a consequence of this fact that more powerful states will exert the greatest influence on the development of international law, and the United States should not hesitate to take the lead in practicing the legitimate doctrine of anticipatory counter-terrorism, counter-proliferation intervention. ${ }^{129}$

\section{Does the UN Charter Permit Anticipatory Self-Defence?}

A significant number of scholars argue that the United Nations Charter precludes any right of anticipatory self- defence. ${ }^{130}$ This argument relies on a restrictive reading of Article 51 of the UN Charter. As discussed earlier, this Article permits the use of force in the event that "an armed attack occurs." ${ }^{131}$ These writers assert that this language, at least by implication, precludes the use of force in anticipation of an attack or other event triggering the right of selfdefence. ${ }^{132}$ The bases for the argument is that, once recognized, a right to anticipatory selfdefence is potentially very difficult to define or limit, and bad faith or an error in judgment

\footnotetext{
${ }^{128}$ Travalio, supra note 118 , at $165-166$.

${ }^{129}$ Posteraro, supra note 67, at 211.

${ }^{130}$ See, e.g., DINSTEIN, supra note 121, at 184- 187; , RICHARD ERICKSON, LEGITIMATE USE OF FORCE AGAINST STATE SPONSORED TERRORISM 136-38 (1989) and authorities cited therein.

${ }^{131}$ UN Charter, art 51.

${ }^{132}$ Whether or not this triggering event must be an "armed attack" is discussed in the prior section of this article. Even if one does not limit the right of self-defense to "armed attacks," the language of the United Nations Charter, Article 51 still reasonably suggests that a triggering event must actually have occurred, not merely be anticipated.
} 
could easily lead to unnecessary conflict. ${ }^{133}$ It is contended that the right to respond with force in self-defence, even to a triggering act that has already occurred, is temporally limited. As the Caroline incident indicates, the customary right of self-defence appears to require immediate action. Otherwise, there is a strong argument that the use of force is nothing more than a reprisal, which, while permitted under limited circumstances by customary international law, is widely agreed to have been outlawed by the United Nations Charter. Even more restrictively, a number of scholars argue that the United Nations Charter precludes any right of anticipatory self-defence. ${ }^{134}$ These writers assert that the language of Article 51 at least by implication precludes the use of force in anticipation of an attack or other event triggering the right of selfdefence. ${ }^{135}$ In the same vein, these legal scholars argue that the right of anticipatory selfdefence expressed by the Caroline incident was overridden by the specific language of the United Nations Charter. In this view, Article 51 fashions a new and more restrictive statement on self-defence, one that relies on the literal qualification of a prior "armed attack." This narrowly technical interpretation perhaps seems to ignore that international law cannot compel any state to wait until it absorbs a devastating or even lethal first strike before acting to protect itself. Strategic circumstances and the consequences of strategic surprise have changed a great deal since the Caroline incident. Today, in an age of chemical/biological/nuclear weaponry, the time available to a vulnerable state could be notably very short.

It is contended that the "armed attack" requirement in Article 51 of the UN Charter seems to supersede any pre-existing right of anticipatory action. Despite this position, Israel and the US have been particularly notorious in seeking to rely upon the concept of anticipatory selfdefence on numerous occasions, with a generally negative response from the international

\footnotetext{
${ }^{133}$ See Mark Baker, Terrorism and the Inherent Right of Self-Defense (A Call to Amend Article 51 of the United Nations Charter), 10 HOUSTON J. INT'L L. 25, 36 (1987).

${ }^{134}$ See, e.g., DINSTEIN, supra note 121, at 184-187); ERICKSON, supra note 130.

${ }^{135}$ See Baker, supra note 133, at 45.
} 
community. As early as 1956, Israel sought to justify its military action across the United Nations armistice line against the feyadeen on this basis. Both the United States and the United Nations rejected this argument. ${ }^{136}$ The anticipatory self-defence argument met with a somewhat better reception in 1967 when the Israelis attacked Egypt and Syria in anticipation of an all-out attack by the Arab states on Israel. Israel justified the strikes that initiated the 1967 Six-Day War on the basis that Egypt's blocking of the Straits of Tiran was a prior act of aggression. Significantly, both the Security Council and the General Assembly refused to condemn Israel for its 1967 pre-emptive attacks against certain Arab states, thereby signifying implicit approval by the United Nations of Israel's lawful resort to anticipatory self-defence. But the permissive international reaction was an exception since most states have refrained from claiming pre-emptive self-defence. International opinion on this issue was never clearer than when Israel attacked an Iraqi nuclear reactor at Osirak in 1981 leaving it in a pile of ruins. Israel argued vehemently that the attack was justified based on the right of anticipatory selfdefence. ${ }^{137}$ The world was outraged and rose up in one voice to condemn the act. The international community's reaction is eloquently captured by Jonathan Steele thus:

\begin{abstract}
The world was outraged by Israel's raid on June 7 1981. "Armed attack in such circumstances cannot be justified. It represents a grave breach of international law," Margaret Thatcher thundered. Jeane Kirkpatrick, the US ambassador to the UN and as stern a lecturer as Britain's then prime minister, described it as "shocking" and compared it to the Soviet invasion of Afghanistan. American newspapers were as fulsome. "Israel's sneak attack ... was an act of inexcusable and shortsighted aggression," said the New York Times. The Los Angeles Times called it "state-sponsored terrorism". The greatest anger erupted at the UN. Israel claimed Saddam Hussein was trying to develop nuclear
\end{abstract}

\footnotetext{
${ }^{136}$ See ERICKSON, supra note 130, at 143.

${ }^{137}$ The United Nations Security Council condemned the Israeli attack on the Iraqi nuclear reactor in a unanimous resolution adopted June 19, 1981. The Security Council also condemned, by a vote of 14-0, with the United States abstaining, the 1985 attack by Israeli F-16s on the PLO Headquarters located in Tunisia. For an excellent discussion of the history of United Nations' responses to various Israeli anti-terrorist campaigns in Lebanon, see O' Brien, supra note 70, at 462-63. The United States appears to have accepted at least a limited doctrine of anticipatory self-defense. Its 1986 attack on Libya was, in part, justified on the basis of deterring future acts of terrorism by Libya. See Statement of Ambassadors Okun and Walters before the UN Security Council, April 1415, 1986, reprinted in 80 AM. J. INT'L L. 632-33 (1986). Former Secretary of State George Schultz stated that the United States is justified in using force to preempt attacks by terrorists or to seize terrorists when no other means are available. See ERICKSON, supra note 130, at 138. Certainly, some of the statements of government officials following the attack on Osama bin Laden and the alleged chemical weapons plant in Sudan seem to assert a broad right of anticipatory self-defense. See, e.g., Paul Richter, U.S. Has Right to Kill Terrorists, Officials Say, DALLAS MORN. NEWS, Oct. 29, 1998.
} 
weapons and it was acting in self-defence, which is legal under Article 51 of the UN Charter. Other countries did not agree. They saw no evidence that Iraq's nuclear energy programme, then in its infancy and certified by the International Atomic Energy Agency as peaceful, could be described as military, aggressive or directed against a particular country. In any case, pre-emptive action by one country against another country which offers no imminent threat is illegal. ${ }^{138}$

The Security Council unanimously passed a Resolution damning the Israeli action as illegal-strong condemnation indeed, especially given that the US was party to it. ${ }^{139}$ Politicians, policymakers and the world at large were unanimous in sensing that Israel's pre-emptive strike was taking the world down a slippery slope. If pre-emption was accepted as legal, the fragile structure of international peace would be undermined. Any state could attack any other under the pretext that it detected a threat, however distant. Notwithstanding this condemnation, five years after the bombing of the Osirak nuclear reactor, the US which had joined the chorus of condemnation bombed Libya after a suspected (now proven) Libyan government agent planted a bomb in a Berlin disco which killed an American serviceman in $1986 .{ }^{140}$ The then US President Ronald Reagan called the action "pre-emptive" on the grounds there was already a pattern of Libyan terrorist actions. ${ }^{141}$ About a decade later, in 1998 after terrorist attacks on US embassies in Kenya and Tanzania, the US fired cruise missiles on the al-Shifa pharmaceutical plant in Sudan. The then US President Bill Clinton argued that it was making chemical and biological weapons for Osama bin Laden, who was assumed (now proven) to be behind the embassy bombings. Clinton said there was "compelling evidence" that the Bin Laden network was planning to mount further attacks against Americans, and he was thereafter entitled to act. ${ }^{142}$ But, apart from a few western governments which approved or kept quiet, most states condemned the Reagan and Clinton air strikes. They did not accept them as legitimate selfdefence under the UN Charter. Even the contentious grounds of anticipatory self-defence and

\footnotetext{
${ }^{138}$ Steele, supra note 2.

139 See U.N. SCOR Resolution 487, 1981 U.N.Y.B. 282, U.N. Sales No. E.84.I.1.

${ }^{140}$ See e.g. Intoccia, supra note 33, at 190 (1987); Reisman, supra note 33, at 33-34 (1999); Bob Woodward \& Patrick E. Tyler, Libyan Cables Intercepted and Decoded, WASHINGTON POST, Washington D.C., (USA) Apr. 15, 1986, at A1

${ }^{141}$ President Ronald Reagan, Address (Apr. 14, 1986), in WASHINGTON POST, Washington D.C., Apr. 15, 1986, at A23.

${ }^{142}$ Arthur Brice, Terror Suspect Says Now It's War, U.S. Ready, Says Official: "We're Going to Be on the Offense as Well as Defense, ATLANTA J. AND CONST., Aug. 22, 1998, at A1.
} 
reprisals provided unsure footing. This is not surprising, in an eloquent observation on the former ground, Professor Christine Gray notes:

[T] he actual invocation of the right to anticipatory self-defence in practice is rare. States clearly prefer to rely on self-defence in response to an armed attack if they possibly can. In practice they prefer to take a wide view of armed attack rather than openly claim anticipatory self- defence. It is only where no conceivable case can be made for this that they resort to anticipatory self-defence. This reluctance expressly to invoke anticipatory self-defence is in itself a clear indication of the doubtful status of this justification for the use of force. States take care to try to secure the widest possible support; they do not invoke a doctrine that they know will be unacceptable to the vast majority of states. ${ }^{143}$

As a matter of principle and policy, anticipatory self-defence is open to certain objections. It involves a determination of the certainty of attack which is extremely difficult to make and necessitates an attempt to ascertain the intention of a government. This process may lead to a serious conflict if there is a mistaken assessment of a situation. Furthermore even if a state is preparing an attack it still has a locus poenitentiae prior to launching its forces against the territory of the intended victim. Nor is the state which considers itself to be the object of military preparations forced to remain supine but may take all necessary precaution before commencing attack. Another consideration which is usually ignored is the effect of the proportionality rule on the problem. It is possible that in a very limited number of situations force might be a reaction proportionate to the danger where there is unequivocal evidence of an intention to launch a devastating attack almost immediately. However, in the great majority of cases to commit a state to an actual conflict when there is only circumstantial evidence of impending attack would be to act in a manner which disregards the requirement of proportionality. To permit anticipatory action may well be to accept a right which is wider than that of self-defence and akin to that of self-preservation. It is true that states must be accorded the right to decide on defensive necessity in the first instance but in making this ex parte decision they should be inhibited by a rule which is related to facts which have objective

\footnotetext{
${ }^{143}$ Christine Gray, INTERNATIONAL LAW AND THE USE OF FORCE 4 (2000).
} 
characteristics and not to mere estimates of intention. ${ }^{144}$

If the correctness of the view is that Article 51 of the UN Charter is the authoritative definition of the right of self-defence and is not qualified or supplemented by the customary law since it subsumes the same is accepted, then states are bound by the black-letter law of the Charter and have less extensive grounds to support armed force undertaken other than within the framework of the UN Charter. ${ }^{145}$ The phrasing of Article 51 was almost certainly not regarded as a novel development of the law by the delegations at San Francisco, and generally speaking by 1945 self-defence was understood to be justified only in case of an attack by the forces of a state. And quite apart from this consideration, the Charter may be regarded as objective or general international law. Firstly, it has received the adherence of every recognized independent state with the states expressly accepting the principles and obligations of the Charter. Secondly, the provisions of the Charter have had strong influence on state practice since 1945 and the terms of Article 51 or very similar terms, have appeared in several important multilateral treaties and draft instruments. Thus Article 3 of the Inter-American Treaty of Reciprocal Assistance of $1947^{146}$ provided for individual or collective self-defence in case of an "armed attack". Articles 18 and 25 of the Bogota Charter of $1948^{147}$ are primarily concerned with reaction to the use of force but the latter article refers ambiguously to "an act of aggression that is not an armed attack" and is concerned only with the application of "measures and procedures", whilst the former merely refers to "the case of self-defence in accordance with existing treaties or fulfilment thereof". The Draft Declaration on Rights and Duties of States adopted by the International Law Commission in 1949 provided in Article 12 that "every State has the right of individual or collective self-defence against armed attack". The

\footnotetext{
${ }^{144}$ BROWNLIE, supra note 7, at 260.

145 BROWNLIE, supra note 7, at 279.

14643 AM. J. INT'L L. (1949), Suppl., p 53. Article 9 refers to "unprovoked armed attack" as aggression within the meaning of the treaty.

14746 AM. J. INT’L L. (1952), Suppl., p 43.
} 
Report of the Commission states that the language is based upon that employed in Article 51 of the UN Charter. Though discussions of the Article by the Commission indicated differences of opinion as to the legality of preventive action prior to an actual attack, all members regarded the right of self-defence as exercisable through the medium of armed force only in the case of the threat of armed attack or actual attack, i.e. as a reaction to the use of force. ${ }^{148}$

It is submitted that there is considerable justification for the conclusion that the right of selfdefence, individual or collective, which has received general acceptance has a content identical with the right expressed in Article 51 of the Charter. Professor M B Baker however argues against the position that Article 2(4) prohibits every form of armed coercion with the exception of the permitted instances in the UN Charter, restrictively read. He opines that:

\begin{abstract}
Article 2(4) of the United Nations Charter does not prohibit every form of armed coercion. The first portion prohibits merely the threat or use of force directed against the territorial integrity or political independence of another state. It is certainly arguable, for example, that armed force used to pre-empt or retaliate against terrorist acts as such or to impose sanctions against a violator of international law is not a use of force directed against the territorial integrity or political independence of another state. The question remains, however, whether or not such uses of force are proscribed under the remaining clause-that prohibiting the threat or use of force 'in any other manner inconsistent with the Purposes of the United Nations. ${ }^{149}$
\end{abstract}

In response, it is contended that in the history of the United Nations, there have been authoritative condemnations of both pre-emptive and retaliatory reprisal actions, ${ }^{150}$ so it seems safe to conclude that both are widely expected to be inconsistent with the purposes of the United Nations and are therefore proscribed under Article 2(4) of the Charter. From a legal viewpoint it should be recognized that characterizations of responding coercion may be conclusory. These and any number of other categorizations of violence such as "intervention," "interdiction," "intercession," "interposition," or "retortion" should be made only after careful

\footnotetext{
${ }^{148}$ YEARBOOK OF THE I. L.C, 108-11, 145-7 (1949).

${ }^{149}$ Baker, supra note 133, at 716-717.

${ }^{150}$ Richard Falk, The Decline of Normative Restraint in International Relations, 10 YALE J. INT'L L. 265,266 (1985). See generally, Levitt, International Law and the U.S. Government's Response to Terrorism, 8 WHITTIER L. REV. 755 (1986).
} 
inquiry into the nuances of context and full realization of the legal policies at stake. Nevertheless, the predominant expectation is that merely pre-emptive and retaliatory reprisal actions as such are impermissible. In light of the UN Charter and in relation to military action against Iraq, C C Posteraro observes that:

[u]less the United States or an ally is a victim of an Iraqi attack, and the US response is in defence against such an attack, it cannot justify a military intervention under the letter of Article 51. Therefore, unless there is an Iraqi military offensive against the United States or its allies, it is unlikely that the United States will be able to make a case that military action against Iraq meets the strict requirements of Article 51. Although the United States has gradually broadened its interpretation of Article 51, it has never claimed a right to act in self-defence unless an armed attack has occurred. The concept of armed attack, however, has proven rather elastic. For the United States to argue that Iraq has perpetrated an armed attack, it will have to rely on less overt actions than past examples of Iraqi aggression against Iran in 1981 and Kuwait in $1990 .^{151}$

Certain international legal scholars "believe that state sponsorship and support of international terrorists constitutes a use of force contemplated by Article 2(4)." ${ }^{152}$ State practice also supports the view that terrorist bombings may constitute an armed attack justifying selfdefence under Article 51. For example, the United States justified its cruise missile attacks against Sudan and Afghanistan following the 1998 terrorist bombings of the US embassies in Tanzania and Kenya, as an exercise of self-defence. ${ }^{153}$ The United States has maintained the policy of considering terrorist bombings armed attacks for some time and has accordingly justified several US military actions against states that have supported terrorists. ${ }^{154}$ In strong support of this position, C C Posteraro states that

... the international community has increasingly agreed that terrorist bombings qualify as armed attacks for the purposes of justifying military action in self-defence. Significant evidence exists that Iraq has supported terrorist operations that target the United States. Therefore, if the United States can establish that Iraq harbours terrorists that have attacked the United States, it can justify military action against Iraq under even a rather strict reading of Article 51. The primary drawback of relying on this justification is that the United States would be required to wait until it has become the target of such an armed attack. ${ }^{155}$

\footnotetext{
${ }^{151}$ Posteraro, supra note 67, at 179-180.

${ }^{152}$ See ERICKSON, supra note 130, at 109, 113.

${ }^{153}$ See Sean D. Murphy, Terrorism and the Concept of "Armed Attack" in Article 51 of the UN Charter, 43 HARV. INT'L L. J. 49-50 (2002) 49-50.

${ }^{154}$ Henkin, supra note 31, at 46; see also Letter from the Acting Permanent Representative of the United States of America, to President of the UN Security Council, United Nations (Apr. 14, 1986), UN SCOR, 41st Sess., UN Doc. S/17990 (1986).

${ }^{155}$ Posteraro, supra note 67, at 180.
} 
The argument is off course that the fundamental shortcoming of reliance on a literal reading of Article 51 to support US action against Iraq is self-evident. The basic problem is that selfdefence is justified only when there has been an armed attack. The nature of weapons of mass destruction is such that the international community could not wait to be the victim of Iraqisponsored chemical, biological or nuclear terrorism otherwise then the notion of self-defence loses any practical meaning. In favourable response to this assertion, it can be said that the Webster formula confined justifiable anticipatory self-defence to circumstances "in which the necessity of that self-defence is instant, overwhelming, and leaving no choice of means, and no moment for deliberation." 156 This recognized standard setting out a method of evaluating claims of self-defence when an armed attack has not yet occurred is however restrictive in relation to weapons of mass destruction. ${ }^{157}$ Though in view of the facts of the Caroline incident and the requirements of the Caroline case only a very narrow category of acts of anticipatory self-defence could be permissible, nonetheless, the restrictive nature of the doctrines of immediacy, necessity and proportionality limited the US flexibility in crafting a military response that would neutralize the Iraqi threat.

Some scholars believe that a right of truly anticipatory self-defence has emerged outside of Article 51 in light of the availability of weapons of mass destruction. ${ }^{158}$ Thomas Frank accounts for the emergence of a viable doctrine of anticipatory self-defence through, "the transformation of weaponry to instruments of overwhelming and instant destruction. These [weapons] brought into question the conditionality of Article 51, which limits states' exercise of the right of self-defence to the aftermath of an armed attack. Inevitably, first-strike

\footnotetext{
${ }^{156}$ The Caroline Incident, supra note 78. Beard, supra note 41, at 585-86.

${ }^{157}$ See ERICKSON, supra note 130, at 109, 111.

${ }^{158}$ BOWETT, supra note 31, at 191-92; see also ERICKSON, id, at 142-43.
} 
capabilities begat a doctrine of "anticipatory self-defence." 159 This position is supported in by Michael Glennon who eloquently lays out five factual contemporary realities that the UN Charter drafters did not have the benefit of more than half a century ago when drafting the document:

Twenty-first-century security needs are different from those imagined [at the founding of the United Nations]. First, . . . the intended safeguard against unlawful threats of force - a vigilant and muscular Security Council - never materialized ... Second, modern methods of intelligence collection, such as satellite imagery and communications intercepts, now make it unnecessary to sit out an actual armed attack to await convincing proof of a state's hostile intent. Third, with the advent of weapons of mass destruction and their availability to international terrorists, the first blow can be devastating - far more devastating than the pinprick attacks on which the old rules were premised. Fourth, terrorist organizations "of global reach" were unknown when Article 51 was drafted. To flourish, they need to conduct training, raise money, and develop and stockpile weaponry-which in turn requires communications equipment, camps, technology, staffing, and offices. All this requires a sanctuary, which only states can provide - and which only states can take away. Fifth, the danger of catalytic war erupting from the use of pre-emptive force has lessened with the end of the Cold War. It made sense to hew to Article 51 during the [Cold War] . . . It makes less sense today, when safe-haven states and terrorist organizations are not themselves possessed of pre-emptive capabilities. ${ }^{160}$

The impact of these factual circumstances on the modern state of self-defence doctrine would appear to be the basis on which some commentators have concluded that a doctrine permitting certain anticipatory self-defence actions is available for states to utilize. ${ }^{161}$ Truly anticipatory self-defence would permit the use of force "[i]f a state has developed the capability of inflicting substantial harm upon another, indicated explicitly or implicitly its willingness or intent to do so, and to all appearances is waiting only for the opportunity to strike." ${ }^{\prime 162}$ It cannot be supposed that the inviolability of territory is so sacrosanct as to mean that a state may harbour within its territory the most blatant preparation for an assault upon another state's independence with impunity; the inviolability of territory is subject to the use of that territory

\footnotetext{
${ }^{159}$ Thomas M. Frank, The Institute for Global Legal Studies Inaugural Colloquium: The UN and the Protection of Human Rights: When if Ever May States Deploy Military Force Without Prior Security Council Authorization? 5 WASH. U. J. L. \& POL'Y 51, 57-58 (2001).

${ }^{160}$ Michael Glennon, Preempting Terrorism; The Case for Anticipatory Self-Defense, WKLY. STANDARD, Jan. 28,2002 , at 24, 26.

${ }^{161}$ ERICKSON, supra note 130, at 149 ("anticipatory self-defense, can be a legal justification for the use of armed force.").

${ }^{162}$ See Michael Glennon, Self-defense and Incoherence in the UN Charter, 25 HARV. J.L. \& PUB. POL'Y 552 (2002).
} 
in a manner which does not involve a threat to the rights of other states. ${ }^{163}$ Supporting this position further is the argument that there is no requirement under the literal letter of Article 51 that a foreign government itself directly undertake the attack to which a state responds. Thus anticipatory self-defence against even the harbouring of terrorists by Iraq may give rise to legitimate, legal justification for an anticipatory US military intervention.

Any such claim, however, is still fundamentally one of self-defence. Therefore, it is still restricted by a number of threshold requirements including imminence, necessity and proportionality. ${ }^{164}$ While the United States can make a case for the necessity of intervening against Iraq, it has a much more difficult time satisfying the proportionality and imminency requirements since it indicated way before the military action that it would undertake the extraordinarily broad intervention at a time and place of its choosing thus effectively jettisoning the proportionality and imminency requirements. ${ }^{165}$ Even allowing for creativity and alluding to the doctrine of "necessity" as a justification for US intervention in Iraq by stretching it to encompass the broad threat posed by the Hussein regime, necessity, however, paradigmatically has been restricted to cases more limited in nature, brief in duration and restricted in responsive means required. Furthermore, necessity constitutes a "ground for precluding the wrongfulness" of otherwise illegal conduct. ${ }^{166}$

\section{Conclusion}

The need for more dramatic targets has led to the new and somewhat exaggerated emphasis on biological, chemical and nuclear weapons. Saddam Hussein's use of poison gas during the

\footnotetext{
${ }^{163}$ BOWETT, supra note 31, at 191-92; see also Erickson, supra note 130, at 54.

${ }^{164}$ See Captain Sean M. Condron, Justification for Unilateral Action in Response to the Iraqi Threat: A critical Analysis of Operation Desert Fox, 161 MIL. L. REV. 115, 147 (1999). Some scholars would further limit the right of anticipatory self-defense, adding inter alia: last resort, reasonableness, and a requirement of reporting to the UN Security Council. See also ERICKSON, supra note 130, at 145-50.

${ }^{165}$ See Condron, $i d$. at 151-52 (discussing the failure of "Operation Desert Fox" to satisfy the proportionality and imminency requirement of anticipatory self-defense).

${ }^{166}$ Cf. John-Alex Romano, Combating Terrorism and Weapon's of Mass Destruction: Reviving the Doctrine of a State of Necessity, 87 GEO.L.J. 1023, 1048-1059 (1999).
} 
Iran-Iraq war and against Kurdish villagers in 1988 was advanced as proof that he would use such weapons against the US today, even though doing so would ensure his own destruction. Iran's desire to acquire a credible deterrent within a nuclear neighbourhood is considered threatening to a country six thousand miles away. What is most striking about the new US policy is that it portrays weapons of mass destruction as a new problem, and unilateral action as the only way of dealing with them.

All in all, the role of multilateral global coalitions or unilateral action in policing "evil-doing" may be increasing and potentially supplanting what initially was designed as the role of the Security Council or the United Nations generally. If supra-national institutions weaken, then decisions regarding the use of force once again become nationalized. National decisions to use force may lead to anarchic, piecemeal, random, and unilateral enforcement of the desirable shared goal of stamping out terrorism. After September 11, states simply may believe, more than before, that they are justified in acting outside the UN system. "A collective, institutional response to terrorism may be more effective than ad hoc unilateralism or narrow coalition building. It may be difficult to prevent ad hoc unilateralism from devolving into self-interested opportunism. Who defines what is an armed attack? A 'threat to the peace'? Who defines when, where, how, and why the use of force can be initiated to contain (or punish) rogue states? If the United States can use extensive military force to respond to terrorism, there is no principled basis to deny others that entitlement."167

It may be prudent for self-defence not to expand so rapidly that it erases the preclusion of unilateral recourse to armed force. After all, as Professor Schachter observes, "[t]he absence of binding judicial or other third-party determinations relating to the use of force adds to the

\footnotetext{
${ }^{167}$ Mark Drumbl, Victimhood in Our Neighborhood: Terrorist Crime, Taliban Guilt, and the Asymmetries of The International Legal Order 81 N.C. L. REV. 1, $32-33$ (2002).
} 
apprehension that a more permissive rule of self-defence will open the way to further disregard of the limits on force." ${ }^{\text {68 }}$ Commenting on an elastic understanding of self-defence as a catalyst for chaos, Professor M Drumbl poses the following pointed questions:

\begin{abstract}
Might India now be able to use force against Pakistan given suspected Pakistani links to terrorism committed in India (for example, attacks against the Indian Parliament undertaken by Kashmiri terrorists)? What about Russian activity in Chechnya, where, in the past, squashing insurrection has led to allegations of systemic human rights abuses? In the post-September 11 world order, is there broader license to use force to crush insurgency movements that may be stigmatised as terrorist? Along with Russia, a number of countries are "now characterizing their own internal struggles as battles against terrorism." Who will defend the world if the use of self-defence becomes opportunistic and colourable? ${ }^{169}$
\end{abstract}

A broad right of anticipatory self-defence would introduce dangerous uncertainties relating to the determination of potential threats justifying pre-emptive action. With this determination being state based the probability of opportunistic interventions justified as anticipatory selfdefence will rise. After all the reality is that only states with the military muscle will be able to make use of this avenue and unilateral action will inevitably be collared by national interest considerations. The development of such a right will likely prompt potential targets into striking first, to use rather than lose their biological, chemical and nuclear weapons. This is not too far-fetched as the increasing volatility in the Korean Peninsula demonstrates. Only those who have no reason to fear military force can contemplate a world without the combined protections of the UN Charter and the customary law of the Caroline case. The US President feels able to claim a broad right of pre-emptive action because other states do not currently have the capacity to retaliate. What Bush fails to realise is that his actions will encourage other states to acquire the very weapons that he purports to abhor.

\footnotetext{
${ }^{168}$ Oscar Schachter, International Law in Theory and Practice 145 (DEVELOPMENTS IN INTERNATIONAL LAW SERIES, Vol. 13, 1991).

${ }^{169}$ Drumbl, supra note 167, at 25-26.
} 